\title{
Constitutional Limitations on the Ability of States to Rehabilitate Their Failed Electric Utility Restructuring Plans
}

\author{
James M. Van Nostrand ${ }^{\dagger}$
}

\section{INTRODUCTION}

In recent years, several states have struggled with the consequences of regulatory regimes they adopted in the late 1990s to restructure the electric utility industry. ${ }^{1}$ When they were implemented, the general pattern of these restructuring plans included an initial rate reduction for various customer classes, followed by a multiyear rate freeze. ${ }^{2}$ The expected result was that during the rate freeze period, competition would develop and power costs would decline over time, so that upon expiration of the rate freeze, rates would not change, or would perhaps even decline. ${ }^{3}$ For the most part, however, the anticipated competition did not develop. ${ }^{4}$ Moreover, during the same period, the cost of generating

\footnotetext{
${ }^{\dagger}$ Executive Director, Pace Law School Energy and Climate Center. B.S., University of Northern Iowa, 1976; J.D., University of Iowa College of Law, 1979; M.A. Economics, State University of New York at Albany, 1985. The author wishes to thank three students (Holly Mancl, Will Kittrell, and J. Scott Childs) who provided assistance on this Article while the author was a Visiting Professor during Fall 2007 at the University of Tennessee College of Law.

1. Rebecca Smith, Emboldened States Take Charge of Energy Issues, WALL STREET JOURNAL, Oct. 12, 2006, at A6. According to Smith,

State officials are asserting more control over their energy destinies ... [by] challenging the electricity deregulation that has been fostered by the federal government in recent years. . . . State officials are especially fearful of political fallout stemming from high electricity rates and disenchantment over the unmet promises of electric-industry deregulation.

Id.

2. See, for example, the restructuring statutes enacted by Maryland, Delaware, Virginia, and Illinois as discussed in Part III of this Article.

3. Smith, supra note 1, at A6 ("Deep, liquid wholesale market-overseen by federal regulators-were expected to give big suppliers good places to shop by attracting numerous power providers. Retail customers, it was thought, would buy juice from those big suppliers, bypassing their local utilities.").

4. Id. ("Much of the current commotion is caused by the fact wholesale electricity markets haven't developed the way people expected. ... Instead, wholesale markets contracted after 2001
} 
power increased significantly, due primarily to increases in the costs of the underlying fuel sources. ${ }^{5}$ When the anticipated benefits of competition failed to materialize, states considered various options for rehabilitating their programs. These included complete abandonment of the restructuring effort or mid-course corrections to the regulatory regimes, such as extending the term of the rate freeze, or requiring rate increases in reduced amounts to be phased in over a period of years.

These rehabilitation efforts can raise serious constitutional questions under a Takings Clause analysis under the Fifth Amendment, and as a matter of procedural due process. This Article will review the constitutional limitations that come into play when a state seeks to rehabilitate its failed electric utility restructuring plan. Under the Constitution, utilities are entitled to earn a reasonable return on the assets devoted to public service. ${ }^{6}$ A situation in which retail rates are frozen may result in denial of a compensatory return if the electric utility is incurring higher costs to generate or procure its power supply. This is the traditional "takings" argument based on the Fifth Amendment to the Constitution, as applied to the states under the Fourteenth Amendment. ${ }^{7}$ Apart from this commonly asserted argument, however, a different constitutional issue arises in the context of proposed rate freezes. As a matter of procedural due process, a regulated utility cannot be deprived of its opportunity to demonstrate a need for rate relief to achieve the level of profitability that satisfies constitutional requirements. ${ }^{8}$ These procedural due process rights are imperiled when, for example, a state simply extends a rate freeze period and thereby denies the electric utility a hearing in which the utility would have an opportunity to make its case for higher rates.

This Article will review these two separate constitutional issues, but will focus primarily on the procedural due process implications that arise in these restructuring controversies. Several cases have recognized and discussed the distinctions between the common "takings" claims and the far less common procedural due process claims that arise when a utility

and millions of consumers remained customers of their local utilities because they didn't have good alternatives.").

5. The Maryland Public Service Commission (Maryland PSC) found, for example, that eastern coal prices increased $69 \%$ and natural gas prices increased $200 \%$ to $300 \%$ between 1999 and 2006 . Moreover, these underlying fuel costs were shown to drive $75 \%$ to $90 \%$ of wholesale electricity prices. Residential Electric Rate Stabilization and Market Transition Plan for the Potomac Edison Company d/b/a Allegheny Power, Case No. 9091, Order No. 81331 (Md. PSC Mar. 30, 2007) [hereinafter Plan].

6. Bluefield Water Works \& Improvement. Co. v. Pub. Serv. Comm'n, 262 U.S. 679, 692-93

7. Duquesne Light Co. v. Barasch, 488 U.S. 299, 307-08 (1989).

8. Mich. Bell Tel.Co. v. Engler, No. 00-73207, 2000 U.S. Dist. LEXIS 20875, at *5 (E.D. Mich., Sept. 14, 2000). 
is denied the ability to demonstrate a need for rate relief. Part II includes a discussion of these leading cases and their applicability to the circumstances when states attempt to rehabilitate electric utility restructuring efforts. Part III continues with a review of illustrative restructuring plans enacted in various states, and how these constitutional issues have, or potentially will, come into play as states struggle with the results of their restructuring regimes.

\section{THE CONSTITUTIONAL LIMITATIONS}

There are two main constitutional limitations applicable to rate regulation: (1) Taking Clause limitations; and (2) Due Process Clause limitations. The discussion of constitutional limitations starts in Section A with the Takings Clause claims commonly asserted by utilities in the context of rate regulation. Takings Clause jurisprudence recognizes that regulated utility companies must be allowed to earn a fair rate of return on their investment. ${ }^{9}$ If a utility regulatory commission fails to grant rate relief in an amount adequate to provide a utility with an opportunity to earn a reasonable return, or denies recovery on a specific utility investment, the utility may have a constitutional claim based on the Takings Clause. Where a utility is denied an opportunity to make a case showing that rate relief is necessary (such as through extension of a rate cap period) a Due Process Clause challenge may be available. ${ }^{10}$ A statute on its face may violate the Due Process Clause if it does not provide a mechanism by which the utility may seek relief from allegedly confiscatory rates. This is in contrast to a Takings Clause claim that the rates resulting from the implementation of the statute are confiscatory. It is a Due Process Clause challenge that may arise in the context of states' efforts to rehabilitate their failed electric utility restructuring plans. Section B of Part II will discuss Due Process Clause jurisprudence and how it potentially arises in the context of utility rate freeze measures.

\section{A. The "Takings" Claim}

The Fifth and Fourteenth amendments to the Constitution prohibit the government from taking private property for public use without just

9. Id. at $47-48$.

10. The Fourteenth Amendment to the United States Constitution provides in pertinent part that no state shall "deprive any person of life, liberty or property without due process of law." U.S. CONST. amend. XIV, § 1 . 
compensation. ${ }^{11}$ These provisions apply to government regulation of maximum rates, and establish a constitutionally-based floor below which a rate ceiling must be reversed as confiscatory. ${ }^{12}$ In determining maximum rates, the courts initially attempted to identify the constitutional floor by reference to an agency's determination of the regulated firm's rate base. ${ }^{13}$ In Bluefield Water Works \& Improvement Co. v. Public Service Commission, the Supreme Court enunciated the constitutional standard for determining the adequacy of a utility's allowed rate of return:

A public utility is entitled to such rates as will permit it to earn a return on the value of the property which it employs for the convenience of the public equal to that generally being made at the same time and in the same general part of the country on investments in other business undertakings which are attended by corresponding risks and uncertainties; but it has no constitutional right to profits such as are realized or anticipated in highly profitable enterprises or speculative ventures. The return should be reasonably sufficient to assure confidence in the financial soundness of the utility and should be adequate, under efficient and economical management, to maintain and support its credit and enable it to raise the money necessary for the proper discharge of its public duties. ${ }^{14}$

Prior to 1944, the courts engaged in a detailed review of each of the three major components used in determining a utility's maximum rates: (1) its rate base; (2) the allowed rate of return; and (3) operating expenses. ${ }^{15}$ In 1944, in Federal Power Commission v. Hope Natural Gas

11. The Fifth Amendment to the United States Constitution provides in pertinent part that "private property" shall not "be taken for public use, without just compensation." U.S. CONST. amend. V, $\S 1$.

12. Ga. R.R. \& Banking Co. v. Smith, 128 U.S. 174, 179 (1888); see also RICHARD J. PIERCE, JR. \& ERNEST GELLHORN, REGULATED INDUSTRIES IN A NUTSHELL 101 (4th ed. 1999).

13. In Smyth v. Ames, for example, the Supreme Court held that rate ceilings must be based on the "fair value" of the property devoted to public service, which was to be determined by considering the following:

[the] original cost of construction, the amount expended in permanent improvements, the amount and market value of its bonds and stock, the present as compared with the original cost of construction, the probable earning capacity of the property under particular rates prescribed by statute, and the sum required to meet operating expenses.

Smyth v. Ames, 169 U.S. 466, 546-47 (1898). According to Pierce \& Gellhorn, "[t]he Court never indicated which of these considerations should control where they are in conflict," but held "that each consideration was to be given 'such weight as may be just and right in each case." PIERCE \& GELLHORN, supra note 12, at 102 (citing McCardle v. Indianapolis Water Co., 272 U.S. 400 (1926)).

14. Bluefield Water Works \& Improvement. Co. v. Pub. Serv. Comm'n, 262 U.S. 679, 692-93 (1923).

15. The constitutionally required rate of retum identified in Bluefield is only one component in the rate-setting process. Rates are designed to achieve a "revenue requirement," which is the amount of dollars the utility should receive during the first year rates are to be in effect. The formula for determining the revenue requirement (Rev. Req.) is as follows: 
Co., the Supreme Court enunciated a different approach that would not require a detailed constitutional review of each component of the ratesetting equation. ${ }^{16}$ Specifically, the Court held that, in setting maximum rates, the utility commission would not be "bound to the use of any single formula or combination of formulae in determining rates." 17 Rather, it would be the "result reached[,] not the method employed" that would be controlling. ${ }^{18}$

Hope involved the rate-setting statute under sections 4 and 5 of the Natural Gas Act,. ${ }^{19}$ According to Hope, "[t]he rate-making process under the Act, i.e., the fixing of 'just and reasonable' rates, involves a balancing of the investor and the consumer interests. ${ }^{20}$ The Court described the investor interest as having "a legitimate concern with the financial integrity of the company whose rates are being regulated, ${ }^{, 21}$ and went on to describe the "company or investor interest" as follows:

It is important that there be enough revenue not only for operating expenses but also for the capital costs of the business. These include service on the debt and dividends on the stock. By that standard the return to the equity owner should be commensurate with returns on investment in other enterprises having corresponding risks. That return, moreover, should be sufficient to assure confidence in the financial integrity of the enterprise, so as to maintain its credit and to attract capital. ${ }^{22}$

Rev. Req. $=($ Rate of Return times Rate Base $)$ plus Operating Expenses

Rate of Return, or cost of capital, is composed of carrying costs on the utility's cost of debt, cost of preferred stock (if any), and the return on equity (ROE) allowed by the commission on common stock. Rate Base consists of the depreciated original cost of the various assets the utility uses in order to provide utility service such as, in the case of an electric utility, its generating plants, poles and wires, and buildings. Operating Expenses are the normal operating costs incurred by the utility in providing utility service, such as salaries, fuel costs, rent, and taxes.

C. Phillips JR., The Regulation OF Public Utilities 157 (1984).

16. Fed. Power Comm'n v. Hope Natural Gas Co., 320 U.S. 591, 602 (1944).

17. Id. at 602 .

18. Id.

19. 15 U.S.C. $\$ 717 c-d(2005)$. Section 4(a) of the Natural Gas Act provides that "all rates and charges made, demanded, or received by any natural-gas company for or in connection with the transportation or sale of natural gas subject to the jurisdiction of the Commission ... shall be just and reasonable, and any such rate or charge that is not just and reasonable is declared to be unlawful." 15 U.S.C. $\$ 717 \mathrm{c}(\mathrm{a})$.

20. Hope, 320 U.S. at 603 (emphasis in original).

21. Id.

22. Id. (internal citation omitted); see also PHILLIPS JR., supra note 15. 
The three tests established by the Court in Bluefield and Hope are commonly referred to as: (1) the comparable earnings test; (2) the financial integrity test; and (3) the attraction of capital test. ${ }^{23}$ According to Bluefield, rates that fail to meet these standards "are unjust, unreasonable and confiscatory, and their enforcement deprives the public utility company of its property in violation of the Fourteenth Amendment."24

The "just and reasonable" standard in utility ratemaking statutes is a term of art, and typically requires a balancing between the interests of the owners of the utility (i.e., the utility investors) and the utility's customers. $^{25}$ This balancing recognizes that while utility customers should pay rates that are reasonable, the rates must be sufficient to produce a profit level that enables the utility to maintain its financial integrity and attract capital. ${ }^{26}$ In turn, these standards require that the interests of utility shareholders be balanced with the interests of utility customers. ${ }^{27}$ In achieving this balance, there is a constitutional minimum, established in Bluefield and reaffirmed by Hope, which must be satisfied. ${ }^{28}$

Thus, any balancing of investor and consumer interests can take place only within the parameters, or zone, of reasonableness, bordered by the two illegal extremes: illegal confiscatory rates at the lower end, and illegal exploitative rates at the upper end. ${ }^{29}$ As stated by Judge Bazelon in Washington Gas Light Co. v. Baker,

there are limits inherent in the statutory mandate that rates be "reasonable, just and non-discriminatory." Among those limits are the

23. Walter Pond, The Law Governing the Fixing of Public Utility Rates: A Response to Recent Judicial and Academic Misconceptions, 41 ADMIN L. REV. 1, 9 (1989); see also Raymond F. Gorman, Martin F. Grace \& Gautam Vora, Public Utility Underwriting Costs and Regulatory Climate: An Examination of PUC and SEC Multiple Jurisdictions, 10 YALE J. ON REG. 17, 30-31 (1993).

24. Bluefield Water Works \& Improvement. Co. v. Pub. Serv. Comm'n, 262 U.S. 679, 690 (1923)

25. Hope, 320 U.S. at 603.

26. Bluefield, 262 U.S. at $692-93$.

27. See Patrick J. McCormick \& Sean B. Cunningham, The Requirements of the "Just and Reasonable" Standard: Legal Bases for Reform of Electric Transmission Rates, 21 ENERGY L. J. 389, 398-99 (2000). The traditional starting point in interpreting the term "just and reasonable" has been an analysis of the Takings Clause implications under the Fifth and Fourteenth Amendments to the Constitution. That article discusses the ratemaking standard under Section 205 of the Federal Power Act, which requires "all rates and charges made, demanded, or received by any public utility for or in connection with the transmission or sale of electric energy subject to the jurisdiction of the Commission" to be "just and reasonable." 16 U.S.C. $\$ 824 \mathrm{~d}(\mathrm{a})(2005)$.

28. The boundaries of discretion have been described by Judge Robert Bork as follows: "In reviewing a rate order courts must determine whether or not the end results of that order constitutes a reasonable balancing ... of the investor interest in maintaining financial integrity and access to capital markets and consumer interest in being charged non-exploitative rates." Jersey Cent. Power \& Light Co. v. Fed. Energy Regulatory Comm'n, 810 F.2d 1168, 1177-78 (D.C. Cir. 1987); see also Mo. Pub. Serv. Comm'n v. Fed. Energy Regulatory Comm'n, 234 F.3d 36, 42 (D.C. Cir. 2000).

29. Pond, supra note 23 , at 30 . 
minimal requirements for protection of investors outlined in the Hope case. And from the earliest cases, the end of public utility regulation has been recognized to be protection of consumers from exorbitant rates. Thus, there is a zone of reasonableness within which rates may properly fall. It is bounded at one end by the investor interest against confiscation and at the other by the consumer interest against exorbitant rates. ${ }^{30}$

The most recent U.S. Supreme Court case that illustrates Takings Clause jurisprudence in a utilities context is Duquesne v. Barasch. ${ }^{31}$ In Duquesne, the utility challenged a Pennsylvania statute that prohibited including expenditures connected with nuclear power plants that were planned, but never built, in the utility's rate base. Notwithstanding the statute, the Pennsylvania Public Utilities Commission (PUC) issued an order that would have allowed Duquesne to collect approximately $\$ 35$ million in rates over ten years as an operating expense to recover a portion of its expenditures on the abandoned plants. In response, Pennsylvania's Consumer Advocate appealed the PUC's decision in the Pennsylvania courts. In affirming the state supreme court's decision, the appeals court ruled that a state scheme of regulation does not "take" a utility's property within the meaning of the Takings Clause simply because it disallows recovery of capital investments that are not "used and useful" in service to the public. ${ }^{32}$

In its Takings Clause analysis, the Duquesne court cited the guiding principle that "the Constitution protects utilities from being limited to a charge for their property serving the public that is so 'unjust' as to be confiscatory." 33 Where the rate set by a state in its ratemaking process does not provide sufficient compensation, "the State has taken the use of utility property without paying just compensation, and so violated the Fifth and Fourteenth Amendments." 34 At the same time, however, the Duquesne court acknowledged that a number of constitutionally

30. Wash. Gas Light Co. v. Baker, 188 F.2d 11, 15 (D.C. Cir. 1950), cert. denied, 340 U.S. 952 (1951).

31. 399 U.S. 299 (1989).

32. Id. at 300 .

33. Id. at 307 (citing FPC v. Texaco Inc., 417 U.S. 380, 391-92 (1974) ("All that is protected, in a constitutional sense, is that the rates fixed by the Commission be higher than a confiscatory leve."); FPC v. Natural Gas Pipeline Co., 315 U.S. 575, 585 (1942) ("By long standing usage in the field of rate regulation, the 'lowest reasonable rate' is one which is not confiscatory in the constitutional sense."); Covington \& Lexington Turnpike Road Co. v. Sandford, I64 U.S. 578, 597 (1896) (A rate is too low if it is "so unjust as to destroy the value of [the] property for all the purposes for which it was acquired," and in so doing "practically deprive[s] the owner of property with out due process of law.").

34. Duquesne, 488 U.S. at 308. 
acceptable methods of fixing utility rates could be used. The court reiterated the analysis of Hope, and stated that many of the subsidiary aspects of ratemaking do not have "a constitutional dimension, despite the fact that they might affect property rights to some degree. ${ }^{35}$ Duquesne affirmed the teachings of Hope, stating that "it is not the theory, but the impact of the rate order which counts." 36 At the same time, Duquesne acknowledged that this "end results" approach used in Hope preserves a utility's ability to raise constitutional takings claims:

This language, of course, does not dispense with all of the constitutional difficulties when a utility raises a claim that the rate which it is permitted to charge is so low as to be confiscatory: whether a particular rate is "unjust" or "unreasonable" will depend to some extent on what is a fair rate of return given the risks under a particular rate setting system, and on the amount of capital upon which the investors are entitled to earn that return. At the margins, these questions have constitutional overtones. ${ }^{37}$

With respect to the "fair rate of return" to which utility investors are entitled in setting "just and reasonable" rates, Duquesne referred to the comparable earnings standard enunciated under Bluefield. This test states that the "return to the equity owner should be commensurate with returns on investments in other enterprises having corresponding risks. ${ }^{\text {"38 }}$ Even though the actions of the Pennsylvania PUC did not result in a constitutionally impermissible rate, the Duquesne decision clarified and confirmed the ability of a utility to assert Takings Clause claims. Specifically, "[t]he Constitution protects the utility from the net effect of the rate order on its property.",39

The difficulty with Takings Clause claims, however, is that the constitutional requirement that a business be permitted a return sufficient to maintain its financial integrity "does not necessarily require any particular level of profit above what is adequate to attract and retain invested capital. ${ }^{, 40}$ As stated by the U.S. Supreme Court in Permian Basin Area

35. Id. at 310 .

36. Id. "If the total effect of the rate order cannot be said to be unreasonable, judicial inquiry $\ldots$ is at an end. The fact that the method employed to reach that result may contain infirmities is not then important." Fed. Power Comm'n v. Hope Natural Gas Co., 320 U.S. 591, 602 (1944).

37. Duquesne Light, 488 U.S. at 310.

38. Id. at 314 (citing Bluefield Water Works \& Improvement. Co. v. Pub. Serv. Comm'n, 262 U.S. 679, 692-93 (1923) ("A public utility is entitled to such rates as will permit it to earn a return ... equal to that generally being made at the same time and in the same general part of the country on investments in other business undertakings which are attended by corresponding risks and uncertainties.")).

39. Id.

40. State Farm Mutual Auto. Ins. Co. v. New Jersey, 590 A.2d 191, 199 (N.J. 1991). 
Rate Cases, "regulation may, consistently with the Constitution, limit stringently the return recovered on the investment, for investors' interests provide only one of the variables in the constitutional calculus of reasonableness. ${ }^{.41}$ As noted above, Hope requires that consideration of the investors' interests must be counterbalanced by consideration of the consumers' interests. ${ }^{42}$ In taking account of the consumers' interests and balancing them against investors' interests, regulators have considerable discretion in determining a fair rate of return when determining "just and reasonable" rates under the rate setting statutes. ${ }^{43}$ Thus, while claims under the Takings Clause provide a legitimate basis for regulated utilities to seek relief from adverse impacts of state restructuring schemes, the likelihood of success of judicial challenges under Takings Clause claims is not great.

\section{B. The Right to Procedural Due Process}

Several leading cases recognize and discuss the difference between the commonly asserted takings argument and a different constitutional issue - procedural due process - that may arise when limitations such as rate freezes are imposed to interfere with the regulated entity's ability to seek rate relief. These procedural due process rights have been recognized for decades in the case of rent control regimes. More recently, these issues have risen in the context of limitations proposed by states on the ability of insurance carriers to increase rates for insurance coverage. The most recent application concern the proposed imposition of rate freezes on regulated utilities.

Birkenfeld v. City of Berkeley ${ }^{44}$ is a 1976 decision from the California Supreme Court which illustrates the procedural due process requirements of a rent control program. In Birkenfeld, a charter amendment adopted by the initiative process required the City of Berkeley to impose residential rent controls. The amendment required a blanket rollback of all controlled rents, and severely limited the city's ability to make any adjustments in maximum rents, except under a unit-by-unit procedure that "would be incapable of effecting necessary adjustments throughout the city within any reasonable period of time." 45 After citing Hope for the proposition that "whether a regulation of prices is reasonable or

41. In re Permian Basin Area Rate Cases, 390 U.S. 747, 769 (1968) (citing Covington \& Lexington Turnpike Road Co. v. Sandford, 164 U.S. 578, 597 (1896)).

42. Hope, 320 U.S. at 603.

43. See PIERCE \& GELLHORN, supra note 12, at 134-44.

44. 550 P.2d 1001 (Cal. 1976).

45. Id. at 1007 . 
confiscatory depends ultimately on the result reached," the California Supreme Court found that a regulation "may be invalid on its face when its terms will not permit those who administer it to avoid confiscatory results." 46 The court invalidated the amendment as "constitutionally deficient" because it "withholds powers by which the rent control board could adjust maximum rents without unreasonable delays and instead requires the [Rent Control] Board to follow an adjustment procedure which would make such delays inevitable.,"47

In a subsequent decision involving a rent control regime, in Fisher v. City of Berkeley ${ }^{48}$ the California Supreme Court again distinguished between the constitutional "fair return" requirements of Hope and the constitutional requirements associated with the procedures whereby landlords could be assured of the opportunity to earn that fair return. In Fisher, the court acknowledged a "veritable smorgasbord" of administrative standards by which to determine rent ceilings. ${ }^{49}$ The court observed that under the standards of Hope, no particular method or formula is required; rather, selection of an administrative standard to fix rents "is a task for local governments ... and not the courts." 50

At issue in Fisher was whether the due process obstacles would prevent the Rent Control Board from avoiding confiscatory results. ${ }^{51}$ In this regard, the court observed that the rent control ordinance "may not indefinitely freeze the dollar amount of [a landlord's] profits without eventually causing confiscatory results." 52 Because the court found that the ordinance was drawn in a sufficiently broad manner, confiscatory results could be avoided, and the ordinance survived a challenge to its facial validity. ${ }^{53}$

The California Supreme Court applied the constitutional due process principles of Birkenfeld several years later when determining the validity of a statewide initiative concerning auto insurance rates. At issue

46. Id. at 1027 .

47. Id. at 1030 (citing Smith v. Ill. Bell Tel. Co., 270 U.S. 587, 591 (1926)) ("Property may be as effectively taken by long continued and unreasonable delay in putting an end to confiscatory rates as by express affirmance of them. ... ."); see also Apartment Ass'n of Greater Los Angeles v. Santa Monica Rent Control Bd., 30 Cal. Rptr. 2d 228, 232 (1994) ("Rent control regulations can have a confiscatory effect if no rent adjustment mechanism is provided, and a regulation may be invalid on its face when its terms will not permit those who administer it to avoid confiscatory results in its application to the complaining parties.").

48. 693 P.2d 261 (Cal. 1984).

49. Id. at 290.

50. Id. at 291 .

51. Id.

52. Id. at 292 (emphasis in original).

53. Id. at 293. In particular, the court noted that nothing in the ordinance precludes the Board from adjusting the percentage rate of return on investment in order to increase a landlord's amount of profits. $I d$. 
in Calfarm Insurance Co. v. Deukmejian ${ }^{54}$ was Proposition 103, passed by the California voters in November 1988, which immediately reduced insurance rates by twenty percent, and placed strict limitations on the ability of the Insurance Commission to allow rate increases during the following year. ${ }^{55}$ The insurance companies argued that the initiative's rate regulation provisions violated the Due Process Clause of the U.S. and California Constitutions because, among other reasons, adequate procedures were not provided to ensure prompt rate relief. ${ }^{56}$ Citing its previous decisions in Birkenfeld and Fisher, the court stated that it would "focus less on the rate specified in the statute than on the ability of the seller to obtain relief if that rate proves confiscatory.

The court recognized that "virtually any law which sets prices may prove confiscatory in practice," and thus the role of the courts is to "carefully scrutinize[] such provisions to ensure that the sellers will have an adequate remedy for relief from confiscatory rates. ${ }^{1,58}$ In this regard, Proposition 103 allowed rates and premiums to be increased during the initial one-year period following enactment, only if the Insurance Commission could find that "an insurer is substantially threatened with insolvency." 59 The court found that while "insolvency" has "various meanings," none of these meanings would allow it to construe this standard "to conform to the constitutional standard of a fair and reasonable return." The effect of the provision was to "bar safely solvent insurers from obtaining rate relief from 'inadequate' rates until November 1989,"61 which "preclude[d] adjustments necessary to achieve the constitutional standard of fair and reasonable rates." ${ }^{\text {"T }}$ The section of the initiative containing the "substantial insolvency" provision was therefore found to be invalid under the due process clauses of the state and federal constitutions. $^{63}$

Following California's lead in enactment of Proposition 103, the Nevada Legislature adopted Chapter 784 in June 1989. This legislation mandated an immediate rollback of motor vehicle liability insurance

54. 771 P.2d 1247 (Cal. 1989).

55. Id. at 1250 (citing CAL. INS. CODE $§ 1861.01(\mathrm{~b})$ ).

56. Id.

57. Id. at 1252.

58. Id. at 1253.

59. Id. (citing CAL. INS. CODE $§ 1861.01(\mathrm{~b})$ ).

60. $I d$.

61. Id. at 1254 .

62. Id. at 1255 .

63. $I d$. at 1256 . The court was able to sever the insolvency provisions from the remainder of Proposition 103 and refused to find the provision for a rollback and reduction of at least twenty percent to violate of the due process rights of insurers. Id. at 1257-59. 
rates to the levels that were in effect on July 1, 1988. This would mean a rate reduction of at least fifteen percent, and a rate freeze for a one-year period from October 1, 1989, until October 1, 1990. ${ }^{64}$ Similar to California Proposition 103, relief from the rate freeze was available only if the Insurance Commission could find that an insurer was "substantially threatened with insolvency" after considering the profitability of all lines of insurance transacted by the insurer within Nevada. ${ }^{65}$ The insurers brought suit in federal court, alleging that Chapter 784 violated due process requirements because it prohibited rate relief to avoid confiscatory results. In Guaranty National Insurance Co. v. Gates, ${ }^{66}$ the Ninth Circuit Court of Appeals agreed with the insurers, finding that Chapter 784 was unconstitutional because it failed to provide "any mechanism to guarantee a constitutionally required fair and reasonable return." ${ }^{, 67}$ In so doing, the Ninth Circuit cited extensively from the procedural due process analysis in Calfarm. ${ }^{68}$

Within the next year, the New Jersey Supreme Court considered a constitutional challenge to the Fair Automobile Insurance Reform Act of $1990{ }^{69}$ which was enacted in order to reduce insurance costs for most New Jersey drivers. ${ }^{70}$ Prior to the Reform Act, New Jersey had adopted a system that allocated high-risk drivers to insurance carriers and that provided such drivers with coverage at rates equivalent to those charged in the "voluntary" market. ${ }^{71}$ The pool to which these high-risk drivers were assigned ultimately accumulated a deficit of over $\$ 3.3$ billion by the

64. Guaranty Nat'l. Ins. Co. v. Gates, 916 F.2d 508, 509 (9th Cir. 1990).

65. Id.

66. Id.

67. Id. at 512. With respect to the constitutional requirement of a "fair and reasonable return," 0the Ninth Circuit stated that "[ $t]$ he concept of a 'fair and reasonable' return as a constitutional standard for regulated industries is derived from early Supreme Court cases discussing the Natural Gas Act of 1938, 15 U.S.C. $\S 717$," which cites the "just and reasonable" rate standard discussed in Federal Power Comm'n v. Natural Gas Pipeline Co., 315 U.S. 575, 581-82 (1942). Id. at 513.

68. Guaranty Nat. Ins. Co., 916 F.2d at 513-15. Unlike the action of the California Supreme Court with respect to Proposition 103, however, the Ninth Circuit was unable to sever the insolvency provisions from the remainder of Chapter 784 as there was no constitutionally permissible standard to take its place. $I d$. at 514 . The Nevada Insurance Code defined rates to be "inadequate if they are clearly insufficient, together with the income from investments attributable to them, to sustain projected losses and expenses in the class of business of which they apply." Id. at 515 (citing NEV. REV. STAT. $\S 686 \mathrm{~B} .050(3)$ ). Given that this definition guarantees only that an insurer will "break even" and "does not guarantee the constitutionally required "fair and reasonable return" required by Hope, "inadequate" is defined "in a constitutionally unacceptable fashion" and the Ninth Circuit was unable to sever the insolvency provision from Chapter 784 and uphold the rest of the measure as the California Supreme Court did in Calfarm. Id.

69. N.J. STAT. ANN. $§$ 17:30A-1-20 (2007).

70. State Farm Mut. Auto. Ins. Co. v. State, 590 A.2d 191, 196 (N.J. 1991).

71. Id. at 195 . 
time the Reform Act was adopted. ${ }^{72}$ One of the objectives of the Reform Act was to pay off this accumulated debt by imposing on insurers a surcharge for "insolvency assessments" and a special surtax for a three-year period. ${ }^{73}$ The insurers challenged the constitutionality of the Reform Act in State Farm Mutual Automobile Insurance Co. v. New Jersey because other provisions of the Reform Act prohibited insurers from passing these new assessments through to policyholders. ${ }^{74}$ The insurers claimed that under the Reform Act, the Commissioner of Insurance was precluded from granting any rate relief to counteract the substantial loss of net income resulting from the new assessments and surtaxes. The insurers argued that this would force them to operate at a loss and deprive them of a constitutionally adequate rate of return. ${ }^{75}$

The New Jersey Supreme Court, after distinguishing between substantive due process claims and takings claims, characterized the essence of the insurers' claim as a confiscatory taking: the substantial additional costs of the new assessments and surtaxes would "necessarily restrict carriers to a negative, or a break-even, or only a minimally positive return." ${ }^{, 6}$ The court agreed with the insurers that the Reform Act absolutely prohibited a pass-through of surtaxes and assessments in the form of direct premium increases or direct rate relief. ${ }^{77}$ Another section of the Reform Act, however, emphasized that insurers were "entitled to earn an adequate rate of return." ${ }^{, 78}$ According to the court, enactment of this section "demonstrate[d] the Legislature's awareness and accommodation of the constitutional requirements that insurers must receive a fair rate of return." ${ }^{, 79}$ Based on this provision, the Department of Insurance issued new regulations that established a special, separate rate-increase filing procedure for any insurer claiming that the effect of the surtaxes and assessments, in its particular case, was to preclude a constitutionally adequate rate of return. ${ }^{80}$ The New Jersey Supreme Court concluded that the Reform Act was not facially unconstitutional as a confiscatory taking because the economic effect of the surtaxes and assessments could be

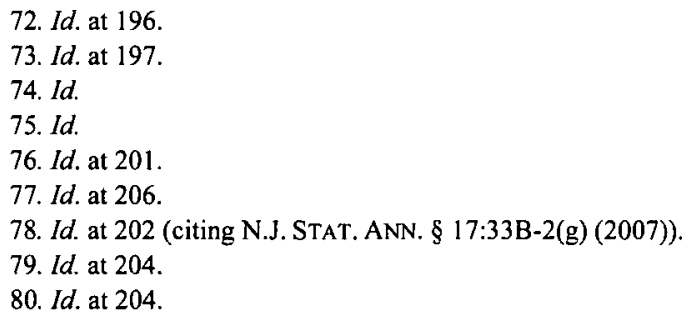


considered in addressing an insurer's claim that it was being deprived of a constitutionally adequate rate of return. ${ }^{81}$

In 2000, the courts addressed the issue of a proposed rate freeze in the context of ratemaking for utility companies. The Michigan State Legislature enacted the Michigan Telecommunications Act of 2000 (MTA) ${ }^{82}$ which included a provision, Section 701 , that froze regulated telephone rates at their May 1, 2000 level until December 31, 2003, except for services deemed competitive by the Michigan Public Service Commission. ${ }^{83}$ Two telephone companies, Ameritech Michigan and Verizon North, challenged the constitutionality of the MTA. These companies claimed that the MTA was "facially unconstitutional" under the Due Process Clause of the Fourteenth Amendment because it did not provide a mechanism through which telephone service providers may ensure that they receive a just and reasonable rate of return on their investment. ${ }^{84}$ In bringing their action, plaintiffs emphasized two decisions: Calfarm and Guaranty National. ${ }^{85}$

In evaluating the attack on the MTA, the U.S. District Court distinguished between claims under the Takings Clause versus those under the Due Process Clause. The court analyzed Duquesne and Hope and concluded that "Takings Clause jurisprudence ... may require that regulated utility companies be allowed to earn a fair rate of return on their investment." ${ }^{, 86}$ Citing Duquesne, the court stated that the "guiding principle" under the Takings Clause "has been that the Constitution protects utilities from being limited to a charge for their property serving the public which is so unjust as to be confiscatory." ${ }^{87}$ The court went on to observe that neither Duquesne nor Hope "dealt with a facial due process challenge" of the kind presented by the telephone companies in this case. The court stated the issue as follows:

[T] he Takings Clause challenge would be an 'as applied' challenge to the result of the statute-i.e., that the rates resulting from the implementation of the statute are confiscatory. That is different from the argument the Court encounters today-namely that the statute on its face violates the Due Process Clause because it provides no

81. Id. at $205-06$.

82. Michigan Telecommunications Act, H.B. No. 5721, 90th Gen. Assem., Reg. Sess. (2000) (codified as amended in scattered sections of MICH. COMP. LAWs $\S 484$ ).

83. Id. Section 710 applied to telephone rates for service providers with more than 250,000 subscribers.

84. Michigan Bell Tel. Co. v. Engler, No. 00-73207, 2000 U.S. Dist. LEXIS 20876 at *4-5 (E.D. Mich. Sept. 14, 2000).

85. Id. at *43-48.

86. Id. at *48 (emphasis in original).

87. Id. (internal citations omitted). 
mechanism by which the Plaintiffs may seek relief from any allegedly confiscatory rates.

The court found the Calfarm and Guaranty National cases "convincing" and held that "the Due Process Clause requires that a state have a mechanism available by which regulated utilities may request relief from allegedly confiscatory rates." ${ }^{.89}$ Given that the three-year rate freeze of Section 701 precluded the operation of such a mechanism "for an unreasonable amount of time," the court found that "serious questions as to the constitutionality" of the rate freeze had been raised and granted an injunction against enforcement of that section of the MTA. ${ }^{90}$

This decision was affirmed by the Sixth Circuit Court of Appeals. ${ }^{91}$ Citing Calfarm, National Guaranty, and State Farm, the Sixth Circuit concluded that "the Due Process Clause requires a mechanism through which a regulated utility may challenge the imposition of rates which may be confiscatory., ${ }^{, 92}$ The court determined that MTA section 701 "does not include any provisions which adequately safeguard against imposition of confiscatory rates," and therefore concluded that the plaintiffs demonstrated a substantial likelihood of showing the provision to be unconstitutional. ${ }^{93}$ Accordingly, the preliminary injunction against enforcing the provision granted by the District Court was upheld. ${ }^{94}$

Within three years, this Due Process Clause analysis was applied in the context of a rate freeze imposed on an electric utility. In Monongahela Power Co. v. Schriber, ${ }^{95}$ an electric utility challenged a provision of the Ohio Restructuring Act that imposed a rate freeze on rates charged to industrial and large commercial customers. The Ohio Restructuring Act, passed by the legislature in June 1999, required electric utilities in Ohio to implement a transition plan that would give customers the right to purchase electricity from competing retail suppliers. ${ }^{96}$ During a "market development period" through December 31,2005, the rates chargeable to retail customers were frozen at pre-Restructuring Act levels. ${ }^{97}$ The Public Utility Commission of Ohio was authorized to provide for an earlier termination of the rate freeze period upon a showing that effective

88. Id. (emphasis in original).

89. Id. at $* 51$.

90. Id.

91. Michigan Bell Tel. Co. v. Engler, 257 F.3d 587 (6th Cir. 2001).

92. Id. at 593 .

93. Id. at 594-96.

94. Id. at 600 .

95. Monongahela Power Co. v. Schriber, 322 F. Supp. 2d 902 (S.D. Ohio 2004).

96. Id. at 907 (citing OHIO REV. CODE ANN. $\$ 4928.31$ (2007)).

97. Id. (citing OHIO REV. CODE ANN. $\$ 4928.40(\mathrm{~B})(2)(2007)$ ). 
competition existed in the utility's service territory or if twenty percent of the utility's load had switched suppliers. ${ }^{98}$

During the intervening period in which Monongahela's transition plan was in effect, the electric utility experienced increases in the cost of the wholesale power supply purchased to serve its industrial and large commercial customers. Monongahela alleged that it was obligated to purchase power at a market price in excess of the rates it was permitted to charge under the rate freeze. It further claimed that if the rate freeze remained in effect through December 31, 2005, it would lose between $\$ 27$ million and \$35 million over a two-year period. ${ }^{99}$ Monongahela contended that the rate freeze provisions of the Ohio Restructuring Act constituted a facial violation of the Due Process Clause of the Fourteenth Amendment, citing the Michigan Bell decision from the Sixth Circuit Court of Appeals. ${ }^{100}$

The court found the Due Process claim in Michigan Bell to be "indistinguishable in all material respects" from the claims of Monongahela. ${ }^{101}$ According to the court, "[t]he particular provisions of the Ohio Restructuring Act that freeze rates and do not provide a mechanism for [Monongahela Power] to challenge its current rates as confiscatory ... are unconstitutional." 102 Because the Act "contains no procedural device which would permit the [Public Utility Commission of Ohio] to determine whether the rates imposed under the Restructuring Act are confiscatory," these provisions violate the Due Process Clause.

\section{Implications with Respect to the States' Restructuring Experience}

The availability of a Due Process Clause challenge under certain circumstances provides a much stronger basis for electric utilities to protect their financial interests in the face of state efforts to rehabilitate their restructuring regimes. If the proposed "fix" involves the imposition of a rate freeze or the extension of a previously agreed-upon rate freeze, the utility may not be limited to the daunting challenge of mounting a Takings Clause claim. A Takings Clause challenge, by its very nature, is an "as applied" challenge to the result of the statute and would require: (1) an evidentiary demonstration regarding the financial results produced by the statute; (2) competing expert testimony offered by the utility and its opponents about the "fair" rate of return necessary for the utility to attract and retain capital; and (3) overcoming the considerable deference

98. Id. (citing OHЮ REV. CODE ANN. § 4928.40(B) (2)(a-b)(2007)).

99. Id. at 911 .

100. Id. at 919 .

101. Id.

102. Id. 
that would be accorded regulators both in making findings about the financial results produced and the required return necessary to be "fair."

Under a Due Process Clause challenge, on the other hand, the utility would have the far easier path as identified in Michigan Bell; "namely that the statute on its face violates the Due Process Clause because it provides no mechanism by which the [utility] may seek relief from any allegedly confiscatory rates." ${ }^{103}$ The utility would be relieved of the burden associated with the Takings Clause challenge; instead, the argument would be that the absence of any mechanism removes the ability of the utility to present the evidence necessary to support a Takings Clause claim. As discussed below, the availability of the Due Process Clause challenge proved to be valuable to electric utilities in protecting their financial interests during the controversies associated with state efforts to rehabilitate restructuring regimes. As these controversies continue to play out in other states, this Due Process Clause remedy will likely receive increasing attention.

\section{THE STATES' RESTRUCTURING EXPERIENCE}

This Part will examine the experience of four states in resolving the controversies that arose in connection with their efforts to restructure the electric utility industry. The underlying circumstances in each state were similar. Each involved restructuring regimes which included multi-year "market transition periods" during which electric rates were frozen or capped, followed by the specter of huge rate increases for residential customers upon the expiration of the rate caps and the transition to "marketbased" prices. The manner in which the controversies were resolved were somewhat different in each state, although a common theme seemed to be a "brinksmanship" approach that ultimately led to a negotiated solution involving all the stakeholders to the process. Each involved proposals with respect to modification of rate freeze periods and provided the utilities with opportunities to assert Due Process Clause claims rather than the more common-and more challenging-Takings Clause claims.

The survey begins with Maryland, which involved a high-stakes political drama that included passage of emergency legislation that would have removed the members of the Maryland Public Service Commission (Maryland PSC). The events were triggered by the prospect of a massive 72 percent increase in the residential rates of Maryland's largest electric

103. Michigan Bell Tel. Co. v. Engler, No. 00-73207, 2000 U.S. Dist. LEXIS 20876 at *40 (E.D. Mich. 2000) (emphasis added). 
utility and ended with a legislatively enacted rate phase-in plan. The possibility of simply extending the duration of the rate caps and triggering a Due Process Clause challenge was rejected in favor of phasing in the required rate increases over a period of years.

The experience in Delaware was much less political, although the rate increases resulting from its "transition" to market rates were nearly as large (59 percent). Delaware also responded by allowing the rate caps to expire, but instead it spread the required rate increase over a longer period through a legislatively enacted rate plan.

In the case of Virginia, its rate caps were not due to expire until 2011; mindful of the experience of its neighboring states of Maryland and Delaware, Virginia anticipated the controversy and avoided it by accelerating the termination of the caps by two years, and implemented a hybrid approach to regulation under which Virginia's utilities would be regulated.

Illinois provides the best illustration of "brinksmanship" and the utilities' ability to assert a Due Process Clause challenge in response to a proposed extension of rate caps. In response to enactment of legislation extending rate caps for an additional three years, Illinois utilities faced downgrades in their credit ratings and claimed the possibility of bankruptcy. A global settlement was ultimately reached under which Illinois utilities collectively provided $\$ 1$ billion dollars of rate relief to customers to assist in paying the higher rates that had taken effect in the "transition" to market rates.

In addition to the examples of these first four states, other states are in the early stages of addressing imminent controversies. In Ohio, for example, the state's rate caps are scheduled to expire on December 31, 2008; this event is expected to result in similarly large rate increases. As in the case of the controversy in Illinois, one of the options being discussed is a possible extension of the existing rate caps beyond 2008 . This would likely trigger the financial community reaction-and potential Due Process Clause challenge-that occurred in Illinois.

\section{A. Maryland}

On April 8, 1999, Maryland Governor Parris Glendening signed into law the Electric Customer Choice and Competition Act (Maryland Restructuring Act). ${ }^{104}$ This act established the legal framework for the restructuring and revised regulation of the electric industry in 
Maryland. ${ }^{105}$ The Maryland PSC cited several objectives in support of moving to a competitive electric market. These objectives included: (1) putting downward pressure on costs and thereby "providing customers with the lowest possible electricity prices"; (2) allowing customers the opportunity to select their electricity supplier; (3) providing "incentives for the creation and development of innovative products and services"; (4) ensuring reliability by creating a competitive market structure to provide power plant developers with the necessary incentives to build additional generation; and (5) attracting new business development, retaining existing businesses, and enhancing overall economic growth in Maryland. ${ }^{106}$

The Maryland Restructuring Act was typical of the restructuring regimes enacted by several states. It achieved a partial restructuring of the supply of electricity, but it did not restructure the transmission and distribution of electricity in the state. ${ }^{107}$ The electric public service companies became "wires" companies and provided the essential transmission and distribution line "links" between customers while the entities provided the electric supply service. ${ }^{108}$ The Maryland Restructuring Act retained the authorized service territories of Maryland's electric utilities, and, within those territories, Maryland's electric utility companies continued to provide regulated transmission and distribution services. ${ }^{109}$ The Maryland PSC continued to regulate the price, terms, and conditions of the delivery of electricity within Maryland. ${ }^{110}$ With respect to the supply of electricity to be delivered to customers, the Maryland Restructuring Act granted customers the ability to choose their electric supplier. ${ }^{111}$ The Maryland PSC was empowered to review applications from competing electricity suppliers and to authorize qualified suppliers to operate in

105. Status Report by the Public Service Commission of Maryland on Electricity Procurement in Maryland, at 1 (Md. PSC Feb. 23, 2005) [hereinafter Status Report], available at http://www.psc.state.md.us/psc/Reports/ElecRestrucWhitePaper2005.pdf.

106. Ten-Year Plan (2006-2015) of Electric Companies in Maryland, at 3 (Md. PSC Dec. 2006), available at http://www.psc.state.md.us/psc/Reports/2006-10YrPlan.pdf.

107. Status Report, supra note 105, at 1-2.

108. Report to the Governor and Maryland General Assembly on the Status of Electric Restructuring and the Structure, Procurement, and Terms of Standard Offer Service, at 2 (Md. PSC Dec. 2006) [hereinafter Report], available at http://www.psc.state.md.us/psc/Reports/ReportonStatusofElectricRestructuring_01022007.pdf.

109. Status Report, supra note 105 , at 2.

110. Id.

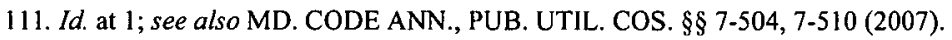


Maryland. ${ }^{112}$ Maryland's investor-owned utilities were also authorized to sell or transfer their generation assets to others. ${ }^{113}$

Under the Maryland Restructuring Act, full retail competition was to begin on July 1, 2002. ${ }^{114}$ The Maryland PSC accelerated restructuring implementation through settlements with all four of the state's investorowned utilities and its two major cooperatives. ${ }^{115}$ Customers of Maryland's investor-owned utilities had the ability to choose their electric supplier as of July 1, 2000, while customers of Maryland's two largest electric cooperatives (Southern Maryland Electric Cooperative and Choptank Electric Cooperative) received this right in 2001. ${ }^{116}$ Municipal utilities and two small co-ops were excluded from a choice mandate. ${ }^{117}$

The Maryland Restructuring Act mandated residential rate cuts ranging from 3 percent to 7.5 percent with rate caps for four years. ${ }^{118}$ Baltimore Gas \& Electric (BGE) reduced electric rates for its residential customers by 6.5 percent in July 2000, and agreed to freeze these rates until June 30, 2006. ${ }^{119}$ BGE also agreed to a rate freeze for its large commercial and industrial customers through June 30, 2002, and for its remaining commercial and industrial customers until June 30, 2004. Delmarva Power \& Light d/b/a Connectiv Power Delivery (Connectiv) reduced electric rates for its residential customers by 7.5 percent in July 2000; it also agreed to freeze rates for all customers through June 30, 2004. ${ }^{120}$ Potomac Electric Power Company (PEPCO) reduced

112. Status Report, supra note 105, at 2. ("As of December 31, 2004, the Maryland PSC had issued 32 electric supplier licenses and 18 electric broker licenses. The Electric Choice Act required potential suppliers to prove their financial qualifications before receiving a license from the Maryland PSC.").

113. Id. at 1 .

114. MD. CODE ANN., PUB. UTIL. COS. $§ 7-510(a)(1)(i v)(2007)$. The Maryland Restructuring Act required the Maryland PSC to designate a supplier in each electric utility's service territory to offer a default electric supply service referred to as standard offer service (Standard Offer). Id. $\$ 7-510$ (c). This service is a generation supply service available to customers who do not choose a competitive electric supplier, or customers who choose a competitive electric supplier and thereafter elect to return to Standard Offer service. Id. $\S 7-510(\mathrm{c})(2)(i v)-(\mathrm{v})$. The Maryland PSC designated each investor-owned utility as the Standard Offer service provider within its own service territory until July 1, 2003. Id. $\$ 7-510$ (c)(3)(i). The Maryland PSC extended this Standard Offer service obligation for all the investor-owned utilities and the two major electric cooperatives. Id. $\S 7-510(\mathrm{c})(3)(\mathrm{ii})$.

115. U.S. Department of Health and Human Services: The Administration for Children and Families, National Energy Affordability and Accessibility Project, Maryland, http://neaap.ncat.org/restructuring/md-re.htm [hereinafter Project] (last visited Nov. 8, 2007).

116. Status Report, supra note 105 , at 1.

117. Project, supra note 115.

118. Id.; see also MD. CODE ANN., PUB. UTIL. COS. § 7-505(d)(1), (d)(4)(i).

119. John Kwoka, Restructuring the U.S. Electric Power Sector: A Review of Recent Studies, AMERICAN PUBLIC POWER ASS'N, at 13 (2006), available at http://www.appanet.org/files/PDFs/RestructuringStudyKwokal .pdf.

120. Id. 
electric rates for its residential customers by 7.0 percent, and reduced electric rates for its non-residential customers by 4.0 percent in July 2000. PEPCO also agreed to freeze rates for all customers through June 30, 2004. ${ }^{121}$ Potomac Edison Company d/b/a Allegheny Power (Allegheny) reduced electric rates for its residential customers in July 2000 , and agreed to freeze these rates through December 31, 2008. ${ }^{122}$ Allegheny's commercial and industrial customers received a rate freeze through December 31, 2004. ${ }^{123}$

The Maryland Restructuring Act also gave direction to the Maryland PSC with respect to the procurement of electric supplies to satisfy the Standard Offer service obligations. That procurement was to be done competitively and at a market price that permitted the recovery of verifiable and prudently incurred costs to obtain or produce the electricity, as well as a reasonable return. ${ }^{124}$ Under the Restructuring Act, the Maryland PSC was to oversee a competitive procurement to determine the market price of electricity. The PSC established a competitive bidding process in Case No. 8908. ${ }^{125}$ The length of each procurement contract depended on the restructuring schedule for each utility and varied between one, two, and three years. ${ }^{126}$ In order to minimize the chance of temporary price spikes due to weather abnormalities, for example, the procurement process established in Case No. 8908 also separated the bidding over a three to four month period that stretched from December of a given year into March of the following year. ${ }^{127}$

Procurements for Standard Offer service were relatively uneventful during the 2003-2004 and 2004-2005 bid periods, although prices trended steadily upward. ${ }^{128}$ In the case of Connectiv, for example, its average bill for small commercial customers decreased by 5 percent upon expiration of the rate freeze in July 2004, while residential customers

121. Id.

122. Status Report, supra note 105 , at 4.

123. Id. The customers of Maryland's two large electric cooperatives received rate benefits as well: Southern Maryland Electric Cooperative (SMECO) on January 1, 2001 and Choptank Electric Cooperative (Choptank) on July 1, 2001. SMECO's customers received a rate reduction of approximately six percent and a rate freeze through December 31, 2004. While Choptank did not reduce its rates, it agreed to freeze its retail prices at the existing rate level through June 30, 2005. Id. at 2,4 .

124. MD. CODE ANN., PUB. UTIL. COS. $\S \S 7-510(c)(3)(i i)(2), 7-510(c)(4)(2007)$.

125. Report, supra note 108, at 3 (citing In re Commission's Inquiry into the Competitive Selection of Electricity Suppliers Standard Offer Service, Case No. 8908).

126. Id.

127. Id.

128. Id. 
experienced an increase of 12 percent. ${ }^{129}$ In 2005 , the total annual bill for Connectiv customers increased by an average of 5.8 percent. ${ }^{130}$ BGE's small commercial and industrial customers experienced an increase of 17 percent upon expiration of the rate freeze in July $2004 .^{131}$ PEPCO's residential and small commercial customers experienced increases of 16 percent upon expiration of the rate freeze in July 2004, and the average annual bill went up another 4.6 percent in 2005 . $^{132}$

Beginning in the summer of 2005 , however, wholesale electric prices in the mid-Atlantic region increased significantly due to increased demand, "coupled with constraints in transmission infrastructure limiting the availability of lower cost generation available to serve that demand." ${ }^{\prime 133}$ As utilities procured energy in late 2005 and early 2006 for delivery in the summer of 2006, prevailing wholesale electricity prices in the market were significantly higher than in previous years. ${ }^{134}$ According to a Maryland PSC report for 2006, bids and prices for standard offer type services in Maryland, the District of Columbia, Delaware, New Jersey, and Pennsylvania all reflected similar price levels due to the increase in natural gas prices and transmission congestion. ${ }^{135}$ In addition, competition did not develop as expected. ${ }^{136}$ As a result, electric supply price increases that occurred from the competitive 2005-2006 procurements produced typical customer bill impacts of a 35 percent to 72 percent increase in annual bills. ${ }^{137}$ In BGE's case, this was the first procurement following expiration of the price caps: 100 percent of its standard offer service load was procured. This resulted in a 72 percent bill increase for residential customers. ${ }^{138}$ Price freeze service had ended in 2003 for PEPCO and Connectiv, and these utilities had previously procured roughly half of their power needs in prior years in multi-year contracts. The blend of these lower priced multi-year contracts with the outcome of

129. Kwoka, supra note 119 , at 13.

130. Id.

131. Id.

132. Id.

133. Report, supra note 108 , at 4.

134. Id. at 3 ("The likely source of these increased prices was a run up in natural gas prices following the catastrophic impacts of Hurricanes Rita and Katrina on the nation's oil and natural gas infrastructure. Natural gas-fired electric plants comprise a significant portion of the fleet of electric generation serving customers in Maryland.”).

135. Id. at 4.

136. Id. at 12 ("[T] $]$ he price freeze components of Maryland's implementation of industry restructuring meant that the newly-licensed suppliers could not compete with the prices available from the utilities during the years of the price freeze periods. That initial stumbling block, combined with the relatively high costs of marketing to small volume customers, constrained the development of retail markets for small customers during the price freeze periods.").

137. Id. at 4 .

138. Id. 
the 2005-2006 procurement produced smaller increases in the 35 to 39 percent range for typical residential customers. ${ }^{139}$

Facing the July 1 expiration of rate caps for BGE, and facing an anticipated 72 percent increase in rates for BGE's residential customers, on March 6, 2006, the Maryland PSC issued Order No. 80638 (March 6 Order). This order adopted a payment plan option for BGE residential customers. The plan adopted by the March 6 Order was an opt-out plan (i.e., customers had to take affirmative action to decline to participate in the plan), included interest charges at five percent and was to last two or three years in duration. In April 2006, BGE filed a comprehensive rate stabilization plan with the Maryland PSC that allowed BGE's residential electric customers to reduce and defer the pending July 1 rate increase. The rate stabilization plan was optional; it would allow BGE customers to select or "opt-in" to a rate stabilization program that would reduce the initial increase and spread out the remainder. Those customers opting in would see a rate increase of 19.4 percent on July $1 .{ }^{140}$

In June 2006, the Maryland state government held a special session to deal with the electricity price crisis. Governor Ehrlich suggested implementing a rate stabilization plan with utilities that would allow customers to limit the rate increase exposure to 15 percent in 2006 , to 25 percent in 2007, and market level in January 2008. Under the Governor's proposal, opting in to this plan would allow customers to repay the deferred charges interest-free. As part of the special session, on June 14, 2006, the Maryland General Assembly considered and passed SB 1. Among other things, SB 1 attempted to terminate (i.e., remove) the incumbent members of the Maryland PSC and attempted to require that their successors be appointed from a list of names provided by the Speaker of the House and the President of the Senate. ${ }^{141}$ SB 1 would also phase in the 72 percent rate increase for BGE and eliminate the

139. Id.

140. Investigation into a Residential Electric Rate Stabilization and Market Transitions Plan for Baltimore Gas and Electric Company, Case No. 9052, Order No. 80764 (Md. PSC Apr. 28, 2006). On April 28, 2006, the Maryland PSC issued Order No. 80764, which modified the March 6 Order to make it an opt-in plan, to treat interest as a deferred asset, and to extend the plan to three and four years. Id. On May 30, 2006, however, the Baltimore City Circuit Court issued an order vacating, reversing, and remanding Order No. 80764. In re Commission's Investigation into a Residential Electric Rate Stabilization and Market Transitions Plan for Baltimore Gas and Electric Company, Case No. 24-C-06-003976 (Md. City Cir. Ct. May 30, 2006), available at http://www.baltocts.state.md.us/about/publications/opinions/PSC_Stay_Order.pdf. In response, on June 2, 2006, the Maryland PSC instructed BGE to implement the March 6 Order. Press Release, Public Service Commission (June 2, 2006) (on file with the Public Service Commission).

141. Schisler v. State, 938 A.2d 57, 60-61 (Md. 2007). 
People's Counsel. ${ }^{142}$ On June 22, 2006, Governor Ehrlich vetoed the bill. In his veto message, Governor Ehrlich stated that the "General Assembly continues to use the PSC as a scapegoat for the failure of the 1999 deregulation law" even though "PSC followed the deregulation law enacted by the General Assembly in 1999 and procedures established by prior PSC members in 2003." 143

On June 23, 2006, the General Assembly resumed its Special Session and voted to override the Governor's veto as an "emergency bill" to take effect immediately. ${ }^{144}$ Chairman Schisler and the Maryland PSC filed a Complaint for a Declaratory Judgment and Temporary Restraining Order in the Circuit Court for Baltimore City on June 26, 2006, and sought to stay Sections 12 and 22 of SB 1, which terminated the commissioners' appointments from taking effect. ${ }^{145}$ On June 28, 2006, the Circuit Court denied relief, and the matter was promptly appealed to the Maryland Court of Appeals. ${ }^{146}$ In a decision issued September 14, 2006, the Maryland Court of Appeals ruled that the state legislature could not dismiss members of the Maryland PSC and nominate its own slate. ${ }^{147}$ According to the ruling, the provision "was an unconstitutional usurpation by the legislature of an executive power."148 The court's decision did not address the other provisions of SB 1, which were not presented in the case.

The phase-in provisions of SB 1 limited the July 1, 2006 rate increase to 15 percent and required all BGE residential customers to participate in a rate stabilization plan. That plan deferred their payment of the difference between the 15 percent increase and the 72 percent increase from July 2006 through May 2007..$^{149}$ On June 1, 2007, standard offer service rates for residential customers were required to go to market rates. ${ }^{150} \mathrm{SB} 1$ further required customers to pay back the deferred amount over a period of ten years, with interest. ${ }^{151}$

142. Id. at 60 .

143. Letter from Governor Robert L. Ehrlich, Jr. to senate President Thomas V. Mike Miller, Jr. (June 22, 2006) (on file with author), available at http://thetentacle.com/docs/sb11.pdf.

144. Schisler, 938 A.2d at 60.

145. Id. at $59-60$.

146. Id. at 60 .

147. Id.

148. See Schisler v. State, 907 A.2d 175, 202 (Md. 2006).

149. 2006 (Special Session) Md. Laws ch. 5 (amending various provisions of the Public Utility Companies article of the Annotated code of Maryland), available at http://mlis.state.md.us/2006s1/bills/sb/sb0001t.pdf.

150. Id.

151. Id. 
The fourth largest utility operating in Maryland, Allegheny Power, has a price cap that is scheduled to expire on December $31,2008 .^{152}$ In December 2006, the Maryland PSC opened a proceeding to investigate measures for avoiding rate shocks when Allegheny's rate caps expire. In commencing the proceeding, the PSC observed that "since 1999, the price of electricity for [Allegheny Power] customers has remained well below market levels ... while the cost of electric utility service, particularly the cost of fossil fuels to generate electricity has increased dramatically." "153 The PSC expressed concern "about the magnitude of the potential price increases affecting residential customers all at once."154

Under the transition plan approved by the Maryland PSC for Allegheny Power on March 30, 2007, customers were offered the choice of participating in an optional program. The program offered customers the choice to transition to the higher market rates on January 1, 2009, by means of a series of surcharges and credits which moderate the impact of moving from capped to market rates. ${ }^{155}$ Under the plan, on March 31, 2007 , Allegheny's residential customers would begin to pay a distribution surcharge that would increase rates by about 15 percent, followed by an additional 15 percent increase on January 1, 2008. ${ }^{156}$ Upon expiration of the rate caps and the move to market-based generation on January 1, 2009 , the surcharge would convert to a credit; funds collected through the surcharge in 2007 and 2008 would be returned to customers as a credit on their electric bills and reduce the impact of the rate cap expiration. ${ }^{157}$ These credits would continue until December $31,2010 .^{158}$

The rate increase borne by BGE's residential customers, however, was limited to 15 percent under SB 1, rather than the 72 percent increase that would have resulted from full implementation of the Standard Offer service market rates. ${ }^{159}$ On March 8, 2007, the Maryland PSC initiated

152. See Plan, supra note 5.

153. Residential Electric Rate Stabilization and Market Transition Plan for the Potomac Edison Company, Case No. 9091, Order No. 81130, at 1 (Md. PSC November 11, 2006). In a press release issued by Allegheny Power at the time it announced its proposed rate stabilization and transition plan, the utility reported that since the beginning of 2001, coal prices had increased 43 percent and natural gas prices had increased 71 percent. In the absence of rate caps, customers' bills would have changed periodically to reflect the true cost of providing electric service. Press Release, Business Wire, Allegheny Power Proposes Transition Plan for Residential Rates in Maryland (Dec. 29, 2006) (on file with Business Wire).

154. Id. at 2.

155. Plan, supra note 5 , at $3-5$.

156. See id.

157. Id.

158. Id.

159. Baltimore Gas \& Electric Company's Proposal to Implement a Rate Stabilization Plan Pursuant to Section 7-548 of the Public Utility Companies Article and the Commission's Inquiry 
the BGE Transition Proceeding ${ }^{160}$ to examine BGE's rates and a proposed rate stabilization plan for June 1 to December 31, 2007. By the time this proceeding commenced, both the Maryland PSC and the Maryland Governor's office had experienced personnel changes. Newly elected Governor Martin O'Malley had issued a campaign pledge to scrutinize conditions that resulted in the expected 72 percent rate increase for BGE customers; he also appointed a new chairman and two new members of the five-member PSC panel. ${ }^{161}$

At the conclusion of the BGE Transition Proceeding, the Maryland PSC issued an order that partly blamed former commissioners for failing to control costs and blamed BGE for acting "passively." 62 In its May 23, 2007 decision, the PSC approved a 50 percent rate increase for BGE's residential customers, representing the balance of the 72 percent increase after reflecting the 15 percent increase allowed by SB 1 and other modest credits included in SB $1 .^{163}$ The PSC concluded that it had "little choice but to approve the proposed increase" and observed that continuing the "artificial" and "illegal rate caps" would "invit[e] costly litigation with little chance of success." 164 The PSC also observed that, when the previous Commission approved settlements that extended the capped rate period for another two years (or until July 1, 2006), ${ }^{165}$ "they set the stage for possible rate shock when the caps were lifted by masking, for an additional two years, the impact of rising energy costs such as

into Factors Impacting Wholesale Electricity Prices, Case No. 9099, Order No. 81423 (Md. PSC May 23, 2007) [hereinafter Proposal].

160. See id.

161. Paul Adams, Rebuilt PSC Begins Hearings to Probe Electricity Rate Rise; Panel Also

Will Weigh BGE Plan to Phase in Future Increases, BALTIMORE SUN, Apr. 17, 2007, at D1. 162. Maryland PSC Approves 'With Reluctance' 50\% BGE Hike, Blaming Old PSC, Utility,

ELECTRIC UTILITY WEEK, May 28, 2007, at 3-4. The Executive Summary states the following: At several junctures, had the Commission taken different action to respond to emerging market conditions and later addressed concerns raised by the General Assembly in Senate Bill 1, it is possible that rates could have been lower than those we are asked to approve in this proceeding. Similarly, BGE, which under the restructuring law essentially is relegated to serving as a conduit of wholesale electricity prices in the provision of [standard offer service], appeared to act passively in light of the same market conditions, rather than proactively attempting to manage large rate increases that were evident on the horizon while rate caps held rates back in check over the period of seven years from 1999 to 2006.

Proposal, supra note 159 , at 4.

163. Proposal, supra note 159 , at 3.

164. Id. at 2, 9. The PSC found there was "no legal basis to invalidate the process or results of [the] procurements." Id. at 9.

165. The Maryland Restructuring Act authorized the PSC to enter into stipulations with the Maryland utilities, and the settlement with BGE extended the rate cap an additional two years beyond the term contemplated in the Act. See MD. CODE ANN., PUB. UTIL. Cos. § 7-505(d)(3) (2006). In the case of PEPCO and Delmarva, for example, the rate caps expired on July 1, 2004. 
natural gas and coal which run generating plants." 166 According to the PSC's analysis, eastern coal prices increased 60 percent, and natural gas prices increased 200 to 300 percent between 1999 and 2006. These energy commodity costs drove 75 to 90 percent of the annual wholesale electricity prices. ${ }^{167}$

The experience in Maryland provided a clear illustration of rate-cap challenges: multi-year rate caps which temporarily insulated retail utility customers from the increases in wholesale power costs, followed by the dilemma of imposing massive rate increases on these customers upon the expiration of the rate caps. The challenges were exacerbated in BGE's case not only by its need to purchase 100 percent of its standard offer service load at then-elevated wholesale market prices, but also its inability to take advantage of the blending of staged purchases that lessened the impact for PEPCO and Connectiv. Simply extending the "artificial" and "illegal" rate caps was not an option, as acknowledged by the Maryland PSC in the BGE Transition Proceeding, because litigation likely would have resulted, and BGE had a strong legal position. Through the procurement process, the actual costs incurred by BGE to serve its retail customers had been quantified: it was not a sustainable solution to deny recovery of these costs through extension of the rate caps. BGE likely would have prevailed on both a Takings Clause challenge and a Due Process Clause challenge. ${ }^{168}$ The solution ultimately implemented was to phase in the undeniably necessary rate increase over a period of years, which was accomplished by the phase-in provisions of SB 1 and the additional measures adopted by the Maryland PSC in the BGE Transition Proceeding.

\section{B. Delaware}

On March 31, 1999, the Electric Restructuring Act of 1999 (Delaware Restructuring Act) was enacted. ${ }^{169}$ Prior to restructuring, the generation, transmission, and distribution of electric power by investorowned utilities was fully regulated by the Delaware Public Service Commission (Delaware PSC). ${ }^{170}$ With restructuring, the generation of electric power became deregulated, leaving only distribution services

166. Proposal, supra note 159 , at $4-5$.

167. Id. at 7 .

168. Although the burden would be more difficult for BGE in the Takings Clause proceeding for the reasons described earlier, the enormity of the wholesale price increases actually incurred by BGE would have resulted in a strong evidentiary record of a confiscatory retum.

169. DEL. CODE ANN. tit. 26, §§ 1001-19 (2006).

170. Electric Regulation in Delaware (Delaware PSC), http://depsc.delaware.gov/electric.shtml (last visited Mar. 1, 2008). 
under the regulatory control of the Delaware PSC. The Delaware Restructuring Act provided for rate caps for customers of Delmarva Power \& Light Company (Delmarva) and the Delaware Electric Cooperative. ${ }^{171}$ In addition, Delmarva residential customers received a 7.5 percent rate reduction. ${ }^{172}$ In April 2001, the Delaware PSC approved a proposed settlement in the merger of Potomac Electric Power Company (PEPCO) and Delmarva Power. Under this settlement, Delmarva was allowed to increase rates about one percent system-wide after September 30,2003, and rates for Delmarva customers were frozen at these levels until May 1, 2006. ${ }^{173}$

Rate caps expired for customers of the Delaware Electric Cooperative on March 31, 2005. ${ }^{174}$ Rates for Delaware Electric Cooperative customers increased about 6 to 8 percent upon the lifting of the caps and increased further in 2007 upon the expiration of long-term purchased power contracts. ${ }^{175}$

Upon the expiration of Delmarva's rate cap on May 1, 2006, Delmarva's rates for residential customers increased by approximately 59 percent. In response, the General Assembly passed a revision to the restructuring legislation entitled "The Electric Utilities Retail Supply Act of 2006." 176 The 2006 Delaware Act automatically enrolled (subject to opt-out by customers) all of Delmarva's residential customers in an electric rate phase-in plan that allowed customers to spread the higher electricity costs over an extended period of time. ${ }^{177}$ Under the phase-in plan, rates increased 15 percent on May 1, 2006, 25 percent on January 1, 2007, and 17 percent on June 1, 2007. Beginning January 1, 2008, customers began to pay back the deferred amount over a 17-month period in monthly installments. ${ }^{178}$

171. Id.

172. Low-Income Home Energy Assistance Program, Overview of Low-Income Restructuring Legislation and Implementation: Delaware (Jan. 2007), http://liheap.ncat.org/dereg/states/delaware.htm.

173. Delmarva Power \& Light Co., Connectiv Commc'ns, Inc., Potomac Elec. Power Co., and New RC, Inc., for Permission to Transfer Control of Delmarva Power \& Light Co., and Connectiv Commc'ns, Inc., Docket No. 01-194, Order No. 5941 (Del. PSC Apr. 16, 2001), available at http://depsc.delaware.gov/orders/5941.pdf.

174. Low-Income Home Energy Assistance Program, supra note 172.

175. Delaware PSC-FAQs, http://depsc.delaware.gov/faqs.shtml (last visited Mar. 1, 2008).

176. Act of April 6, 2006, 143rd General Assembly (2006) (2006 Delaware Act), available at http://legis.delaware.gov/lis/lis 143.nsf/vwLegislation/HB+6?Opendocument (follow "Legis.doc" hyperlink).

177. Id. $\S 3$.

178. Id. $\S 5$. 
Additional provisions of the 2006 Delaware Act were intended to stabilize long-term pricing in the Delmarva service territory. ${ }^{179}$ The provisions allowed distribution companies to enter into long and shortterm supply contracts, own and operate generation facilities, build generation and transmission facilities, make investments in demand-side resources, and take any other Commission-approved action to diversify the retail load supply. ${ }^{180}$ Furthermore, the 2006 Delaware Act required Delmarva to conduct Integrated Resource Planning for a forward-looking 10-year period. ${ }^{181}$ As part of the initial planning process, Delmarva was also required to file a proposal to obtain long-term supply contracts. ${ }^{182}$ The proposal required Delmarva to include a Request for Proposal (RFP) for the construction of new generation resources within Delaware. ${ }^{183}$

The experience in Delaware was very similar to Maryland's in terms of the magnitude of the necessary rate increase (59 percent increase for Delmarva versus a 72 percent increase for BGE) and the ultimate legislative solution (a multi-year phase-in of the rate increases necessary to recover the higher wholesale power costs). As in Maryland, it would not have been a legally sustainable solution to extend the duration of Delmarva's price caps, given the evidence of the higher wholesale power costs actually incurred by Delmarva in serving its retail customers. Under the phase-in adopted in the 2006 Delaware Act, Delmarva was ultimately made whole for the higher power costs through customers' payment of deferred amounts. Other provisions of the 2006 Delaware Act were intended to provide a long-term solution to the underlying procurement issue and eliminate exclusive reliance on periodic procurements in the wholesale markets by essentially restoring the vertically integrated utility and by permitting Delmarva to enter into long-term contracts and construct utility-owned generation.

\section{Virginia}

In March 1999, the Virginia Electric Utility Restructuring Act (SB 1269) passed the General Assembly and was signed into law by the Governor. $^{184}$ The Virginia Restructuring Act provided for deregulation of generation by January 1, 2002, and a phase-in of consumer choice be-

179. Synopsis of 2006 Delaware Act, Delaware General Assembly, available at http://legis.delaware.gov/lis/lis143.nsf/vwLegislation/HB+6?Opendocument.

180. Act of April 6, 2006, supra note 176, $\S 6(\mathrm{~b})$.

181. Id. $\S 6(\mathrm{c})$.

182. Id. $\S 6(\mathrm{~d})$.

183. Id.

184. VA. CODE ANN. $§ 23-56-567$. (2007) (Virginia Restructuring Act). 
tween January 1, 2002, and January 1, 2004. ${ }^{185}$ For those customers not switching electricity providers and remaining with their incumbent utility, rates were capped through July $2007 .^{186}$

In the annual report to the Legislative Transition Task Force in August 2001, the Virginia State Corporation Commission (Virginia SCC) reported on the implementation of pilot programs for retail access commenced by Dominion Virginia Power (DVP) and American Electric Power (AEP) in the fall of 2000 and by Rappahannock Electric Cooperative (Rappahonnock) in January 2001. ${ }^{187}$ According to the report, "the pilot programs did not attract the anticipated level of interest from either customers or suppliers." 188

In its August 2002 report, the Virginia SCC stated that only 2,500 residential consumers and twenty-four small commercial customers were using an alternative supplier. Residential customers who had switched were customers of a competitive provider offering "green" power at a price higher than the incumbent utility's price-to-compare. ${ }^{189}$ The report observed that competitive providers "view the Virginia retail market as currently providing little economic incentive for entry."190

In its 2003 status report, the Virginia SCC recommended suspending restructuring in the state. ${ }^{191}$ The report expressed "substantial doubt as to the ability of retail electric competition to provide, at the present time, lower prices for Virginians than would have been charged under the traditional regulation of the industry." 192

In April 2004, Governor Mark Warner signed SB 651 which extended the retail electricity rate cap through $2010 .{ }^{193}$ The bill also allowed DVP to hold its fuel rate at its present level until July 1, 2007, after which one adjustment was permitted for the three-and-a-half year

185. See id. § 56-577.

186. See id. $\S 56-582$.

187. Dev. of a Competitive Retail Market for Elec. Generation within the Commonwealth of Virginia, Part I, Executive Summary (Va. SCC Aug. 31, 2001), available at http://www.scc.virginia.gov/caseinfo/pue/case/statusreportpartlexecsum.pdf.

188. Id. at 1 .

189. Dev. of a Competitive Retail Market for Elec. Generation within the Commonwealth of Virginia, Part I, Executive Summary (Va. SCC Aug. 31, 2002), available at http://www.scc.virginia.gov/caseinfo/reports/02_lttf_exsum_l.pdf.

190. Id.

191. Dev. of a Competitive Retail Market for Elec. Generation within the Commonwealth of Virginia, Introduction (Va. SCC Aug. 29, 2003), available at http:/www.scc.virginia.gov/caseinfo/reports/2003_1.pdf.

192. Id. at $\mathrm{v}$.

193. Act of April 14, 2004, 2004 S.B. 651, $\S 56-249.6(\mathrm{C})$ (2004), available at http://legl.state.va.us/cgi-bin/legp504.exe?041+ful+CHAP0827 (amending various sections of VA. CODE ANN. § 56). 
period ending December 31, 2010. ${ }^{194}$ Also, the bill expanded local government options to form buying groups to save money on electricity for their citizens and set up procedures to make it easier for many large commercial and industrial consumers to switch electricity suppliers. ${ }^{195}$

On the heels of the recent experience in Maryland and Delaware with regard to the challenges associated with expiring rate caps, in its September 2006 report the Virginia SCC began to express concern about the impact of expiring rate caps on electricity prices in Virginia. The report noted that because the Virginia Restructuring Act was enacted in 1999, "electric utility customers in Virginia have been insulated, to some degree, from changes in electric charges that would otherwise apply in the absence of the base rate caps which are an integral component of Virginia's restructuring program." 196 According to the report, the effect of the base rate caps "has kept retail prices for most Virginia consumers from increasing precipitously despite escalating prices for electricity in wholesale markets."197 The report noted the experience of retail electric customers in neighboring states (Maryland and Delaware) which "faced precipitous electricity cost increases as applicable rate caps have expired." "198 According to the report, "the basic problem is that today's prevailing wholesale prices are much higher than those envisioned at the onset of industry restructuring." 199

The Legislative Transition Task Force, established under the Virginia Restructuring Act, began to study the implications of the expiration of capped rates at the end of 2011. ${ }^{200}$ In its December 2006 meeting, the Task Force considered a variety of proposals, including a proposal to extend the rate caps and other modifications to the restructuring regime. ${ }^{201}$ When the Virginia legislature convened in January 2007, a number of competing proposals emerged. State Senator Thomas K. Norment introduced legislation supported by DVP that would replace the

194. Id

195. Id. $\$ 56-589$.

196. Dev. of a Competitive Retail Market for Elec. Generation within the Commonwealth of Virginia, Introduction, at $\mathrm{i}$ (Va. SCC Sept. 1, 2006), available at http://www.scc.virginia.gov/caseinfo/reports/2006_intro.pdf.

197. Id.

198. Id. at ii.

199. Id.

200. Greg Edwards, Will Virginia Face Future Shock on Electricity Bills?: Lawmakers Will Study Deregulation After Big Increases in Md., Del., RiCHMOND TIMES-DiSPATcH, Sept. 29, 2006, at B9.

201. See Greg Edwards, Panel to Hear Utility Proposals: Extending Rate Caps, Revising Deregulation, Encouraging Renewables Addressed in Bills, RICHMOND TIMES-DISPATCH, Dec. 16, 2006 , at B13. 
state's deregulated electric power market with a hybrid form of regulation. According to Senator Norment's Bill (Norment Bill) Virginia SCC would review electric utilities' rates every two years and would allow utilities to keep all profits up to a three percent return above national averages over utilities' long-term bond costs. ${ }^{202}$ Additionally, the rate caps would terminate at the end of 2008 , rather than at the end of $2010 .{ }^{203} \mathrm{~A}$ competing proposal offered by House Delegate Harvey Morgan would have ended the current cap on rates on December 31, 2007, and would have required the Virginia SCC to reset electric utility rates at that point based on the utility's cost of service or the traditional form of rate regulation. ${ }^{204}$

Thereafter, the Virginia Attorney General's Office facilitated a compromise between the competing proposals and among the various stakeholder groups. ${ }^{205}$ The outcome of that process was a bill sponsored by House Delegate Clarke N. Hogan, H.B. 3068 (Hogan Bill), which would have stripped much of the rate-setting flexibility from the Virginia SCC by enacting formulae for rate floors and requirements for rate changes. ${ }^{206}$ The Hogan Bill would have set a ceiling on returns that a utility would be allowed to earn at two percentage points above the national average return on equity earned by regulated utilities. ${ }^{207}$

The final bill that emerged, SB 1416, was signed by Governor Tim Kaine in April 2007, and included several amendments that the Governor had required. ${ }^{208}$ The bill advanced the scheduled expiration of the capped rate period from December 31, 2010, to December 31, 2008. ${ }^{209}$ The bill also established a new mechanism for regulating the rates of investor-owned electric utilities and limited the ability of most consumers to purchase electric generation service from competing suppliers.

202. See Greg Edwards \& Pamela Stallsmith, Committee Passes Electricity Bill: Senate Measure Would Create Hybrid Form of Regulation, Encourage Building New Plants, RICHMOND TiMESDisPaTCH, Feb. 6, 2007, at B7.

203. See Dominion Puts Forward Plan for Virginia to Return to Cost-of-Service Rate Regulation, Global POWER RePORT, Jan. 4, 2007, at 1.

204. Debate Kicks off on Virginia's Retail Program with Effort to Negotiate, GLOBAL POWER REPORT, Jan. 15, 2007, at 1.

205. Chris Flores, Dominion OKs Compromise with Virginia: The Utility Has Agreed to Restore More Authority to the State Regarding Profit Margins, NEWPORT NEwS DaILY PRESS, Jan. 31, 2007.

206. Greg Edwards, Legislators Agree Deregulation Failed: Deregulation's Failure Apparent; Next Approach to Electric Restructuring is What is at Issue, RICHMOND TIMES-DisPaTCH, Feb. 2, 2007, at C6.

207. Id.

208. See Virginia Governor Amends State's Rereg Bill to Allow Competitive Bids for New Generation, GLOBAL POWER REPORT, Mar. 29, 2007, at 22.

209. VA. CODE ANN. § 56-582(F) (2007). 
The ratemaking procedure requires the Virginia SCC to conduct a rate case for investor-owned utilities in 2009, and thereafter for the rates, terms, and conditions of each utility biennially. ${ }^{210}$ In these biennial reviews, the SCC is to set a utility's basic allowable rate of return on equity at a level at least equal to the average of the rates of return allowed for other, similar utilities in the southeast. ${ }^{211}$ With respect to the customer's ability to purchase generation services from competing providers, the bill provided that after the capped rate period ends, only customers with annual demand in excess of five megawatts will be permitted to shop. ${ }^{212}$

Stakeholders in Virginia obviously benefited from examining the earlier experience of Maryland and Delaware with the undesirable transition issues that occurred at the expiration of multi-year rate caps. Although one option considered in Virginia was to extend the rate caps beyond 2010, the Virginia SCC's analysis highlighted the problem with continuing to insulate customers from the price increases that were occurring in the wholesale markets. Rather than allow this "mismatch" between retail prices and wholesale costs to continue until 2011, and run the risk of "transition" rate increases even larger than those experienced in Maryland and Delaware, the solution in Virginia was to accelerate the termination of the rate caps, and to return to a form of cost-based rate regulation under which retail customers would receive the signals of higher prices in the wholesale markets. How this plan ultimately plays out will be determined when the Virginia utilities undergo their required rate case review in 2009.

\section{Illinois}

In December 1997, the Illinois legislature passed H.B. 362, "The Electric Service Customer Choice and Rate Relief Act of 1997" (Illinois Restructuring Act). ${ }^{213}$ The Illinois Restructuring Act provided for rate cuts of fifteen percent for the residential customers of the state's two largest utilities, Commonwealth Edison (ComEd) and Ameren's Illinois Power subsidiary (AmerenIP), effective August 1998, followed by an additional five percent rate reduction in May 2002. ${ }^{214}$ Smaller utilities were required to phase in five percent reductions by May 2002. ${ }^{215}$ The

210. See id. $\S 56-585.1$.

211. See id. $\S 56-585.1(\mathrm{~A})(2)(\mathrm{b})$.

212. Id. $\S 56-577(\mathrm{~A})(3)$.

213. 220 ILL. COMP. STAT. 5/16-101-130 (2007) (Illinois Restructuring Act).

214. Id. at 5/16-111(b).

215. Id. 
Illinois Restructuring Act also required retail access for commercial and industrial customers to choose their electricity provider by October 1999. All customers, including residential, were able to choose their generation supplier by May 2002. ${ }^{216}$ The Act also imposed a ten-year freeze on electric rates through January $1,2007 .^{217}$

In July 1999, SB 24 was enacted to amend the Illinois Restructuring Act. The amendment accelerated the date for the transition to customer choice. The first third of commercial and industrial consumers would have retail access by October 1, 1999, the second third by June 1, 2000, and the final third by October 1,2000. As of January 1, 2001, all commercial and industrial customers were eligible for retail access to competitive suppliers. In addition, the required five percent rate reduction for residential customers was accelerated by seven months, to October 1 , 2001.

During the first two years of the restricted environment in Illinois, the results concerning customers' exercise of their competitive options were somewhat mixed. ${ }^{218}$ The majority of customers that switched to alternative suppliers were in ComEd's territory, while the downstate utilities were experiencing very low customer participation levels. ${ }^{219}$ The

216. See id. at $5 / 16-111.5$

217. $I d$. at $5 / 16-111.5 \mathrm{~A}$. The rate freeze period was meant to provide a transition period from a completely regulated industry to a market-based industry. Post 2006 Initiative: Final Staff Report to the Commission, at 1 (Ill. Commerce Comm'n Dec. 2, 2004), available at http://www.icc.illinois.gov/downloads/public/en/041203ecPostRptFinal.doc.

218. In December 2000, the Illinois Commerce Commission (ICC) issued an update on the status of competition in the State.

219. About $12 \%$ of ComEd's eligible customers representing about half of the company's load had switched to alternative suppliers. Illinois Restructuring Active, http://www.eia.doe.gov/cneaf/electricity/page/restructuring/illinois.html (last visited Mar. 1, 2008). $6.9 \%$ of AmerenIP's customers had switched, while AmerenCIPS had $6.8 \%$ of its customers switch. Id. Illinois Power (AmerenIP) is a subsidiary of Ameren; Central Illinois Public Service Company (AmerenCIPS) is also a subsidiary of Ameren. Ameren Wikipedia Entry, http://en.wikipedia.org/wiki/Ameren (last visited Mar. 1, 2008). The ICC Report stated that a lack of competition could be due to a need for more suppliers, electricity shortages, inefficient transmission system, a lack of uniform interconnection standards, or the lack of restructuring activity in the surrounding states. Assessment of Competition in the Illinois Electric Industry in 2002 (IIl. Comm. Comm'n Apr. 2003), available at http://www.icc.illinois.gov/downloads/public/en/030513garpt16120.doc.

In the ICC's April 2001 "Assessment of Retail and Wholesale Market Competition in the Illinois Electric Industry," the commission concluded that only in the ComEd service territory were switching rates and supplier activity high in 2000 . Illinois Restructuring Active, supra, note 19. In the ComEd service territory, approximately $22 \%$ of eligible customers had switched to delivery services, and $62 \%$ of eligible usage had switched from bundled to delivery services. Assessment of Competition in the Illinois Electric Industry. At the end of 2000 , about eight suppliers were active in the ComEd service territory, although only three or four suppliers had acquired a fairly significant number of customers. Id. In the downstate territories, by contrast, few suppliers were operating. Id. In its April 2002 "Assessment of Retail and Wholesale Market Competition in the Illinois Electric Industry in 2001 ," the ICC reported that $14 \%$ of the load eligible for delivery services had switched 
response to this lack of success was SB 2081, designed to provide time for the competitive market to develop in Illinois by extending the utility rate freeze and mandatory transition charges for an additional two years in June $2002 .{ }^{220}$

In August 2002, the Illinois Commerce Commission (ICC) released the Report of Chairman's Summer 2002 Roundtable Discussion Re: Implementation of the Illinois Restructuring Act. The report stated that "there is absolutely no competition (or choice) for retail residential electric customers, and it is unlikely competition (or choice) will be available for these customers for the next several years. ${ }^{, 221}$ The report further stated that commercial and industrial retail customers had limited access to alternative retail electric suppliers outside of the ComEd service territory. 222

In the absence of the increased competition that was expected to develop, the ICC began to consider how to price electricity when the transition period ended and the rate caps expired on January 1, 2007. ${ }^{223}$ As a result of the Illinois Restructuring Act, ComEd and the Ameren utilities became distribution-only utilities that sold or spun off their generating assets to affiliates. ${ }^{224}$ In other words, ComEd and the Ameren utilities could only serve their retail customers with electricity by entering into wholesale contracts with other companies. ${ }^{225}$ The initial wholesale power contracts that ComEd and the Ameren companies entered into expired with the end of the Illinois Restructuring Act's mandatory transition period on January $1,2007 .{ }^{226}$ The ICC staff issued a report to the ICC on December 2, 2004, containing recommendations regarding the procurement of electricity by Illinois utilities after the end of the transition period. ${ }^{227}$ In February 2005, both ComEd and Ameren filed proposals for auction processes to determine prices that would be passed

to a retail electric supplier and that eighteen suppliers were licensed retail electric suppliers in 2001 . Id.

220. Act of June 7, 2002, Pub. Act 92-0537, 2001 Ill. Laws 537 (2002).

221. ICC, REPORT OF THE Chairman's SumMER 2002 Roundtable Discussion Re: IMPLEMENTATION OF THE ILLINOIS RESTRUCTURING ACT.

222. Id.

223. Illinois Commerce Commission, Post 2006 Initiative: Final Staff Report to the Commission, at 1 (Dec. 2, 2004) available at http://www.icc.illinois.gov/downloads/public/en/041203ecPostRptFinal.doc.

224. See The September 2006 Illinois Auction, Post-Auction Public Report of the Staff, at 4 (ICC Dec. 6, 2006) [hereinafter Post Auction Report], available at http://www.icc.illinois.gov /downloads/public/en/Post_Auction_Public_Report_Auction_manager.pdf.

225. Id. at 4-5.

226. $I d$.

227. Id. at 4 
on to their customers after conclusion of the transition period. ${ }^{228}$ In January 2006, in the Procurement Dockets, the ICC found that the best option available for ComEd and Ameren to acquire new wholesale power contracts for delivery starting January 2007 would be an open auction where all bids from competing suppliers would be evaluated uniformly on the basis of price. ${ }^{229}$

The first auction was held in September 2006. As a result of the auction, the rates for most residential electricity consumers were expected to increase significantly on January 1, 2007. According to the Staff Audit Report, ComEd's rates would increase by 21 percent, ${ }^{230}$ AmerenIP's rates would increase by 37 percent, AmerenCIPS' rates would increase by 36 percent, and Ameren CILCO's rates would increase by 53 percent. ${ }^{231}$

In response to the auction results, lawmakers proposed an extension of the rate caps through the year 2010. In February 2006, H.B. 5766 was introduced in the House to amend the Illinois Restructuring Act. ${ }^{232}$ This bill provided for an extension of the mandatory transition period. ${ }^{233}$ Furthermore, the bill prohibited the ICC from taking certain actions prior to 2010 with respect to (1) initiating, authorizing, or ordering any change by way of increase in an electric utility's rates, or (2) approving an application for a merger, imposing a condition requiring any filing for an increase, decrease, or change in or other review of an electric utility's rates, or enforcing such a condition. ${ }^{234}$ In October 2006, H.B. 5766 was approved by a House committee. ${ }^{235}$

Debt rating agencies downgraded both ComEd and Ameren in response to the possible rate freeze action. ${ }^{236}$ Standard \& Poor's Ratings

228. See Commonwealth Edison Company, Docket No. 05-0159 (Feb. 25, 2005) (proposal), available at http:/www.icc.illinois.gov/downloads/public/edocket/161341.pdf; see Suspended Supplemental Information for Ameren (Feb. 28, 2005), available at http://icc.illinois.gov/eDocket/docketnumber05-160.

229. See ICC, ORDER - FINAL FOR AMEREN (Jan. 24, 2006), available at http://icc.illinois.gov/e-Docket/docketnumber05-160. Ameren proposed what is known as a "vertical tranche multi-round descending clock auction" for purposes of acquiring power and energy after the end of the transition period on January 1, 2007. See id. at 5.

230. For residential customers without space heating.

231. See Post-Auction Public Report, supra note 224, at v.

232. Exelon Prepared to do Battle in Court if Illinois Lawmakers Extend Rate Freeze, ELECTRIC UTILITY WEEK, Oct. 30, 2006, at 7.

233. Id

234. 220 ILl. COMP. STAT. 5/16-111(a) (2007).

235. Illinois Rate Freeze Extension Bill Approved by House Panel; Senate Action Uncertain, ELECTRIC UTILITY WEEK, Oct. 16, 2006, at 1.

236. Id. On October 5, 2006, Standard \& Poor's Ratings downgraded ComEd two notches, downgraded Ameren and its utility units, and kept the utilities on Credit Watch Negative. On October 10, Fitch Ratings put Ameren on Rating Watch Negative, and Moody's Investors Service put Ameren, AmerenCILCO, AmerenCIPS, AmerenUE, and ComEd on review for downgrade. Id. 
indicated that "if the legislation is passed, S\&P will lower its ratings on the Illinois utilities into the B category.",237 ComEd promised to "mount a vigorous court battle" if Illinois lawmakers passed the rate freeze legislation. ${ }^{238}$ ComEd's legal challenge was based on both Due Process Clause and Takings Clause claims. ${ }^{239}$ Ameren, for its part, indicated that it had hired bankruptcy lawyers in anticipation of the impacts of the Illinois rate freeze, "which would drive the company's utilities there into bankruptcy as soon as February." Without a rate increase, Ameren claimed its Illinois utilities would lose $\$ 2.5$ million per day. As a result, Ameren would be downgraded to "junk" status and would not be able to buy electricity or natural gas. ${ }^{240}$

The 2006 legislative session ended without resolution of the rate freeze issue. On November 30 , the state senate passed a plan offered by senate President Emil Jones which provided for a three-year phase-in of rate increases. Under the legislation, amended House Bill 2197, rates would have gone up 7 percent in both 2007 and 2008 and 8 percent in 2009 , with any additional costs recovered, without interest, over a threeyear period starting in $2010 .{ }^{241}$ The House had passed a different bill by a $65-33$ vote. This bill, H.B.607, would have extended the existing rate freeze by three years. ${ }^{242}$

In December 2006, the ICC approved a plan to phase in Ameren's and ComEd's rate hikes. The planned program would allow most Ameren customers the option to reduce their rate hike to a maximum of 13.25 percent for each of the next three years (2007-2009) and defer the additional amount to a three-year repayment period beginning in $2010{ }^{243}$ The program would also allow ComEd's residential customers to reduce their rate hike to a maximum of 10 percent for each of the next three

237. Id.

238. Exelon Prepared to do Battle in Court if Illinois Lawmakers Extend Rate Freeze, ELECTRIC UTILITY WEEK, Oct. 30, 2006, at 7. John Rowe, Chairman, President and CEO of Exelon, ComEd's parent, stated that "ComEd's legal team already has all the necessary papers prepared for legal challenge" if the General Assembly approves HB 5766. Id.

239. Telephone interview with Darryl M. Bradford, Senior Vice President and General Counsel, Commonwealth Edison Company (Oct. 29, 2007).

240. Id.

241. Illinois Legislators Adjourn Veto Session Stalemated over ComEd/Ameren Rate Issue, ELECTRIC UTILITY WEEKLY, Dec. 4, 2006, at 19.

242. Id.

243. See ICC Resolves Remaining Issues on 2007 Electricity Rates, PR NEWSWIRE, Dec. 20, 2006. 
years (2007-2009) and to defer the additional amount to a three-year repayment period beginning in $2010{ }^{244}$

In a brief legislative session in early January 2007, the Illinois House approved S. 1714, which would extend the rate caps by an additional three years and also roll-back the rate increases threatening Illinois customers at the time. ${ }^{245}$ The bill passed in the House, but the measure was not considered by the senate. ${ }^{246}$ The regular 2007 session convened on February 6, and shortly thereafter, the House passed the rate freeze extension bill again. ${ }^{247}$ Standard \& Poor's Ratings Services indicated that its debt rating on ComEd's first mortgage bonds remained on CreditWatch with negative implications and stated that "[i]f widespread support for a statewide electric freeze surfaces in the senate, making passage of a rate-freeze bill all but certain, [it] could lower ComEd's ratings, perhaps precipitously." ${ }^{248}$ The senate passed its version of a three-year rate freeze bill, SB 1592, on April 20, 2007..$^{249}$ SB 1592 also provided for rolling back electric rates to their 2006 levels for at least a year, and prevented ComEd and Ameren from shutting off power to non-paying residential customers until December 1, 2007. ${ }^{250}$

The stakes changed later in the spring when House Speaker Michael Madigan began to propose a tax on electric generation. Under his plan, a tax of $\$ 70,000$ per megawatt of nameplate capacity would be imposed on most generation facilities in Illinois. This would cost Exelon Generation, a ComEd affiliate, about $\$ 775$ million annually. ${ }^{251}$ An amendment sponsored by State Representative George Scully included the generator tax in SB $1592 .{ }^{252}$ In negotiations, ComEd and Ameren responded by offering $\$ 500$ million to help customers pay electric bills;

244. Illinois Commerce Commission Approves Rate Phase-In Plans for ComEd, Ameren, ELECTRIC UTILITY WEEKLY, Dec. 25, 2006, at 21.

245. CUB Applauds House Vote on Rate Freeze Extension, Urges Senate to Send Bill to Governor for $O K$, PR NEWSWIRE, Jan. 7, 2007.

246. Id; Rowe Says Illinois Stalemate Could Endure; Merrill Sees that as an Acceptable Outcome, ELECTRIC UTILITY WEEKLY, Jan. 20, 2007, at 2.

247. See ComEd: House Passage of Rate Freeze Extension Threatens Reliable Electric Service in Illinois, PR NEWSWIRE, Mar. 6, 2007.

248. S\&P, Commonwealth Edison's 'BBB'-Rated $\$ 325 M$ Bonds Remain on Watch Neg, Mar. 16, 2007.

249. Ameren Says Illinois Senate Legislation is Unconstitutional and Not in Best Interest of Illinois: Immediate Relief to Electric Customers at Risk, PR NEwSWIRE, Apr. 20, 2007. ComEd was exempted from the legislation under a "rare parliamentary move" by Senate President Emil Jones, but ComEd was re-inserted when the measure was sent to the House. Illinois Legislature Considers Generation Tax as Overtime Session Looms, ELECTRIC UTILITY WEEK, May 28, 2007, at 1.

250. Adriana Colindres, House Panel Puts ComEd in Rate Freeze, ST. J.-REg (SPRINGfield, ILL.), Apr. 27, 2007.

251. Illinois Legislature Considers Generation Tax as an Overtime Session Looms, ELECTRIC UTILITY WEEK, May 28, 2007, at 1.

252. Id. 
ComEd's share would be $\$ 300$ million and Ameren's share would be $\$ 200$ million. $^{253}$ The amended SB 1592 was approved by a House committee in late May $2007 .^{254}$ State Senator Gary Forby, the sponsor of SB 1592, stated that an acceptable negotiated settlement would be preferable to passing a freeze bill and then "spending the next three years in court since ComEd and Ameren have vowed to appeal any such legislation.,255

The months of negotiation among the utilities, senate President Emil Jones, House Speaker Mike Madigan, and Attorney General Lisa Madigan resulted in a comprehensive statewide settlement announced on July 24, 2007. The Illinois Power Agency Act ${ }^{256}$ (Power Agency Act) was signed by Governor Rod Blagojevich on August 28, 2007. The Power Agency Act provided approximately one billion dollars in rate relief over four years for residential and certain non-residential electric customers. $^{257}$ Approximately $\$ 540$ million of the rate relief was made available during 2007 , with the remaining amount to be provided in 2008,2009 , and 2010. ${ }^{258}$ Exelon Generation provided $\$ 747$ million of the funding, Ameren provided $\$ 150$ million, ComEd provided $\$ 53$ million, Midwest Generation and Dynegy each provided $\$ 25$ million, and MidAmerican Energy Company contributed $\$ 1$ million. ${ }^{259}$ Of the one billion dollars of relief, $\$ 488$ million was allocated to ComEd customers, while the Ameren utilities received about $\$ 250$ million. ${ }^{260}$

In addition to rate relief, the Power Agency Act established a new regulatory regime to oversee the utility power procurement process in Illinois, including the creation of the Illinois Power Agency, a new state agency to oversee a competitive power procurement process. ${ }^{261}$ The agency will retain a procurement administrator that will manage an alternative competitive process for procurement on behalf of the utilities' residential and small business customers. ${ }^{262}$ The alternative procurement process will include competitive requests for proposals and will direct

253. Id.

254. Illinois General Assembly Fails to Resolve Electric Rate Relief Issue. Heads for Overtime, ELECTRIC UTILITY WeEK, June 4, 2007, at 7.

255. Id.

256. Pub. Act 95-481, 2007 Ill. Laws 481 (2007) [hereinafter Power Agency Act].

257. ComEd to Participate in Comprehensive, Statewide Settlement of Electric Rate Debate, TRANSMISSION AND DISTRIBUTION WORLD, July 25, 2007, available at http://tdworld.com/customer_service/comed-electric-rate-debate/.

258. Id.

259. Id.

260. Id.

261. Power Agency Act, supra note 257, § 1-15.

262. Id. § 1-70. 
the purchase of power in separate base load, intermediate, and peaking blocks beginning in $2008 .^{263}$ In addition, the agency will house a resource development function that could build power plants and sell output to Illinois municipalities and co-ops. ${ }^{264}$ The Power Agency Act also imposes new energy efficiency and demand response requirements on electric utilities and provides for new renewable portfolio standards. ${ }^{265}$

The rating agencies reacted favorably to the enactment of the Power Agency Act. Standard \& Poor's announced in late July that, upon enactment of the law, it would remove the Ameren utilities as well as Exelon and its ComEd subsidiary from the "CreditWatch with negative implications" category ${ }^{266}$ and affirmed this action in late August. ${ }^{267}$ Fitch Ratings similarly affirmed and removed Ameren and its Illinois companies (CILCO, CIPS and IP) from Rating Watch Negative on August 1, $2007,{ }^{268}$ and upgraded various of ComEd's issuances in late $\mathrm{Au}-$ gust 2007. ${ }^{269}$

The Illinois experience is noteworthy in several respects. First, there was an actual legislative enactment of a rate freeze extension, which would have extended the existing rate freezes by an additional three years. The amount of the necessary rate increase to match wholesale costs with retail rates had been quantified through the procurement process (requiring rate increases between 21 percent and 53 percent), and the legislature was simply going to deny the utilities a forum for making the case to increase retail rates to recover these costs. Second, the utilities were prepared to mount their legal challenges to the rate freeze: a Due Process Clause challenge was obvious and ComEd was prepared to make it, along with a Takings Clause challenge. Ameren had already "done the math" for its Takings Clause challenge: it would lose $\$ 2.5$ million per day under the rate freeze, and its bonds would quickly be downgraded to "junk" status. Third, the financial community confirmed the financial irresponsibility of enacting a rate freeze by issuing warnings of imminent downgrades of securities of affected utilities. Retail customers

263. Id. $\S 1-75$.

264. Id. $\S 1-80$.

265. Id. $\$ 1-75$.

266. Energy Central News, S\&P: Ameren Corp. Avoids Rate Freeze with Rate Relief Pact; Favorable for Creditworthiness, July 23, 2007; Energy Central News, S\&P: Exelon Agreement that Forestalls Rate Freeze in Illinois is Favorable for Credit, July 24, 2007.

267. Energy Central News, S\&P: Exelon, Ameren Ratings Affirmed After Illinois Agreement Becomes Law; Off Watch, Aug. 29, 2007.

268. Fitch Affirms and Removes Ameren and Illinois Subsidiaries from Rating Watch Negative, BUSINESS WIRE, Aug. 1, 2007.

269. Fitch Upgrades Commonwealth Edison's IDR to ' $B B+$ ' from ' $B B$ ' on Illinois Rate Legislation, BUSINESS WIRE, Aug. 29, 2007. 
would long bear the consequences of the higher borrowing costs that would result from these downgrades, and the policymakers in Illinois could not ignore these warnings.

Although the utilities had a very strong legal position with respect to their rights to recover the higher wholesale power costs in retail rates, it was the threat of a generation tax that broke the stalemate. Under the Illinois Restructuring Act, ComEd and Ameren had sold or spun off their generating assets to affiliates. While the regulated retail utilities bore the impacts of the mismatch between wholesale power costs and retail electric rates, the unregulated generation affiliates of ComEd and Ameren were reaping the benefits and profits associated with the higher wholesale prices. The generation tax proposed by House Speaker Madigan would provide a way to capture a portion of these profits, and his proposed tax of $\$ 70,000$ per megawatt of nameplate capacity would raise about $\$ 775$ million annually from Exelon generation alone. This brought the utilities to the bargaining table and forced an abandonment of the promised Due Process and Takings Clause challenges. Ultimately, the retail electric utilities were allowed to raise their rates to recover the higher wholesale power costs, but the unregulated generating companies operating in Illinois coughed up one billion dollars, of which $\$ 747$ million was provided by Exelon Generation, to help retail customers pay the higher rates. Although the constitutional legal rights of the regulated utilities were compelling, the Illinois political leaders had a trump card of their own through their credible threat to impose a generation tax that would peel away much of the profits derived from wholesale power transactions. The compromises embodied in the Power Agency Act ended the legislative deadlock and provided a long-term solution to the underlying issue of power procurement in the restructured market.

\section{E. Preliminary Activities in Other States}

While the rate cap expiration issues have been addressed in Maryland, Delaware, Virginia, and Illinois, other states will soon be facing the same issues. Policymakers in Ohio, for example, are exploring options for dealing with rate caps that expire at the end of 2008. Pennsylvania has taken affirmative steps to address the transition issues expected to occur when its rate caps expire within the next two years, and New York and Michigan are both considering legislative proposals that could roll back restructuring efforts in these respective states. Maine is embarking on a more limited rollback, while Montana has all but abandoned its failed restructuring experiment. The controversial and somewhat notorious experiences in Maryland and Illinois will certainly inform the proc- 
esses in these states as they move forward. Utilities in these states will likely have Due Process and Takings Clause protections that may come into play if rate cap extensions are proposed as a possible solution.

\section{Ohio}

After years of lobbying from electric utilities and many consumers, on October 5, 1999, the Ohio General Assembly passed SB 3, which provided for restructuring of Ohio's electric-utility industry. The bill's goal was to achieve retail competition with respect to the generation component of electric service. ${ }^{270}$ The Ohio Restructuring Law provided for a transition period, termed the "market development period," during which an electric utility's rates would be subject to certain regulatory requirements. ${ }^{271}$

During the market development period of January 1, 2001, through December 31,2005 , rates were frozen to allow a competitive wholesale market to take shape. The deregulation plan allowed incumbent utilities to recover 100 percent of their stranded costs (\$11 billion total) without any proceedings to determine their validity. Consumers could not switch electric companies without a surcharge for stranded costs being added to their utility bills. Many believe that this policy severely handicapped competition from the start. ${ }^{272}$ By the end of the market development period, the limited number of competitive electric suppliers led the Public Utilities Commission of Ohio (Ohio PUC) to develop three-year rate stabilization plans (RSPs) in order to minimize the effects of "sticker shock" and gradually transition customers to market-based rates. The current RSPs are to last from January 1, 2006, until December 31, $2008 .{ }^{273}$

In October 2003, a legislative report encouraged the Ohio PUC to "continue to take the necessary steps . . . to ensure that a healthy competitive market is in place before full electric competition begins." ${ }^{.274}$ This report was an important source of the legislative support for the Ohio PUC's development of RSPs, and RSPs were put in place for AEP, Dayton Power \& Light (DP\&L), Duke Energy Ohio, and FirstEnergy. ${ }^{275}$

270. Am. Sub. S.B. 3 (1999), available at http://www.legislature.state.oh.us/BillText123/123_SB_3_ENR.html (amending various sections of Ohio's Revised Code).

271. Ohio Consumers' Counsel v. PUC, 847 N.E.2d 1184, 1187 (Ohio 2006).

272. See Dennis J. Willard, All Sides of Debate Agree: Ohio Energy Prices to Rise, AKRON BEACON JOURNAL, Oct. 21, 2007.

273. The Market Development Period, OHIO PuBlic UTILITIES COMMISSION, http://www.puco.ohio.gov/PUCO/Consumer/information.cfm?id=6102 (last visited Feb. 24, 2008).

274. $I d$.

275. Id. 
In May 2007, with the impending expiration of the Rate Stabilization Plans, Ohio legislators and utility regulators began "working on a preemptive plan to avoid the potential rate shock that could ensue in 2009 when Ohio investor-owned utilities are required to procure power at market prices, following the termination of existing rate stabilization plans."276 Ohio Governor Ted Strickland responded by announcing a platform for utility reforms called the "Energy Compact," which sought a "principled, well-considered approach" to issues affecting the electricity market. ${ }^{277}$ On August 29, 2007, Governor Strickland announced that his Energy Compact would include requirements that 25 percent of the electricity of Ohio be generated by "advanced energy technologies," and that at least half of this electricity would come from renewable sources. ${ }^{278}$

On October 31, 2007, the Ohio Senate passed Governor Strickland's Energy, Jobs, and Progress Bill (SB 221). ${ }^{279}$ This bill had been amended several times, and would freeze rates upon the expiration of the RSPs and implement a hybrid approach to ratemaking thereafter. ${ }^{280}$ The bill would require utilities to get permission from the Ohio PUC to move to market-based rates. Upon such a request for permission, the Ohio PUC would consider the state of the market and the current, regulated price. The bill would also let utilities negotiate with affiliates for rates to charge consumers for power without any regulatory review. The debate is expected to continue throughout 2008 , given that the current Rate Sta-

276. Fitch Report: Proposed Ohio Electric Restructuring Legislation Spurs Uncertainty, BUSINESS WiRE, Dec. 17, 2007.

277. The principles of the Energy Compact include:

- Restoring lost faith in government and public utilities by designing clear, common-sense plans and being responsible for accomplishing them.

- Giving electric customers equal footing with utility companies so the public understands the issues involved in electric power decision-making.

- Making energy efficiency a central element in addressing electric regulation.

- Stimulating consumption of renewable energy sources to attract investment in advanced energy technology.

- Modernizing Ohio's electric infrastructure.

- Taking into account environmental issues, especially global warming, and integrating them as a guiding concern in electricity regulation.

Strickland: Ohio Needs to Fix Electric Deregulation, BUS. COURIER OF CINCINNATI, May 1, 2007, available at http://www.bizjournals.com/cincinnati/stories/2007/04/30/daily23.html.

278. Businesses Counting on Strickland Plan to Avert Energy Bill Spike, DAYTON DAILY

NEWS, Aug. 31, 2007, available at http://www.redorbit.com/news/business/1050922/businesses_counting_on_strickland_plan_to_avert _energy_bill_spike/index.html.

279. See Paul Wilson, Electricity-Regulation Bill Wins Senate Approval, THE CoLUMBUS DisPaTCH, Nov. 1, 2007, at 10C.

280. Sub. S.B. No. $221 \S 4928.17,127$ th Ohio Gen. Assem. (amending various sections of Ohio's Revised Code). 
bilization Plans in Ohio are scheduled to expire on December 31, $2008{ }^{281}$ According to an industry observer, the relevant parties to the proceedings have expressed widely divergent opinions regarding the value of competitive markets. ${ }^{282}$ The Ohio Industrial Energy Users, for example, argued that an appropriately structured competitive market had yet to materialize and that competitive markets could not be relied upon for the procurement of electricity. ${ }^{283}$ One rating agency, Fitch Ratings, noted the "uncertainty caused by the legislative debate, as well as certain provisions of [SB 221], was a source of ongoing concern for investors,"284 and stated that an outcome "that would restrict the companies' ability to recover power supply costs . . . could lead to future negative credit rating actions." 285

\section{Pennsylvania}

In Pennsylvania, ${ }^{286}$ upon the December 31, 2005 expiration of rate caps for Pike County Light and Power Company, 4,400 Pike customers experienced an increase of over 70 percent in their total electric bill at the beginning of $2006 .{ }^{287}$ The generation rate cap of PPL Electric Utilities (PPL) is scheduled to expire at the end of $2009 .{ }^{288}$ The generation rate caps of PECO Energy Company, West Penn Power Company, Metropolitan Edison Company, and Pennsylvania Electric Company are due to expire at the end of $2010 .{ }^{289}$ In May 2006, the Pennsylvania Public Utility Commission (Pennsylvania PUC) cited the events in Maryland and Delaware to show that "consumers of electricity can be exposed to sudden, dramatic price increases when long-term generation price caps, mandated or agreed upon as part of various state restructuring proceedings, expire. ${ }^{290}$ Therefore, Pennsylvania PUC commenced a proceeding to develop policies to address potential electric rate increases that follow

281. Restructuring Today, Ohio's SB 221 Passes Senate, Heads for House, Nov. 1, 2007, http://www.restructuringtoday.com/public/12703.cfm.

282. Fitch Ratings, Ohio SB 221: Deregulation, Reregulation and Creditworthiness, Dec. 14, 2007 , at 2 .

283. Id.

284. Id. at 1 .

285. Id.

286. In December 1996, Pennsylvania enacted House Bill 1509, the Electricity Generation Customer Choice and Competition Act, which required utilities to submit restructuring plans by September 1997. Pennsylvania Restructuring Active, http://www.eia.doe.gov/cneaf/electricity/page/restructuring/pennsylvania.html (last visited Mar. 1, 2008).

287. Investigation Order, Docket No. M-00061957, at 15 (Penn. PUC May 24, 2006), available at http://www.puc.state.pa.us/PcDocs/611864.

288. Id. at 3 n. 4 .

289. Id.

290. Id. at 1 . 
the expiration of generation rate caps. ${ }^{291}$ Notably, the PUC did not raise the possibility of merely extending the rate caps; in its Tentative Order, the PUC "raised the idea of either phasing in rate increases prior to the expiration of rate caps, or deferring some portion of the rate increases to later years." ${ }^{292}$

Some elected officials, on the other hand, proposed an extension of the rate caps in reaction to the expected rate increases, and Pennsylvania Governor Ed Rendel had indicated he would sign a bill if it included "reasonable" rate caps. ${ }^{293}$ One state senator indicated she was considering a bill to extend the rate cap on what PPL could charge customers for electricity generation. ${ }^{294} \mathrm{PPL}$, for its part, is "vehemently opposed" to an extension, which it says would push the company into bankruptcy. ${ }^{295}$

The final order issued in the May 2007 proceeding outlined the need for a statewide consumer education campaign to prepare electricity ratepayers for potential increases, as well as to provide information about energy efficiency, conservation, and demand-side response. ${ }^{296}$ In response to the anticipated expiration of its rate cap in 2010, PPL proposed a "competitive bridge plan" designed to ease the impact of higher prices. ${ }^{297}$ Under its bridge plan, which the Pennsylvania PUC approved in May 2007, the utility would conduct a series of up to six auctions in 2007, 2008, and 2009 for power supplies needed in 2010, thereby producing a "blend" of contracts that would minimize the rate impact. ${ }^{298}$ Even after taking into account the rate mitigating impacts of this proposal, PPL expected its customers' bills to increase by about 35 percent in 2010 for residential customers and up to 42 percent for some businesses. ${ }^{299}$ PPL, therefore, proposed a five-year plan that would allow

291. See id. at 1-3.

292. Tentative Order, Docket No. M-00061957, at 17 (Penn. PUC Feb. 13, 2007), available at http://www.puc.state.pa.us/PcDocs/653886.doc.

293. Jeanne Bonner, PPL Files Bid for Phased Rate Hike: Company Says Impact Will be Less if It's Not All Imposed at Once, THE MORNING CALL, Dec. 4, 2007, at D1.

294. Sam Kennedy, Is Free Market For Electricity a Done Deal? Cap on Generation Charges Set to Expire in State at End of 2009, and Lawmakers Might Fight Big Rate Hike, THE MORNING CALL, Aug. 19, 2007, at D1.

295. Id.

296. See Final Order, Docket No. M-00061957 (Penn. PUC May 17, 2007), available at http://www.puc.state.pa.us/PcDocs/662103.doc.

297. Pennsylvania PUC Votes to Approve PPL Plan to Make Extended Bid for Post Rate-Cap Power, GLOBAL POWER REPORT, May 17, 2007, at 19.

298. Id.

299. Jeanne Bonner, PPL Files Bid for Phased Rate Hike: Company Says Impact Will be Less if It's Not All Imposed at Once, THE MORNING CALL, Dec. 4, 2007, at D1. According to PPL, since the rate caps were established in the late 1990s, increases in fuel costs-natural gas up 250 percent and coals costs up 55 percent-have resulted in higher wholesale prices. Pennsylvania PUC Votes 
customers to start making additional payments in their electric bills beginning in mid-2008, continuing through the end of 2009. ${ }^{300}$ Money from those payments, plus interest, would be applied to bills in 2010, 2011 , and 2012. ${ }^{301}$

\section{New York}

There are some preliminary discussions in New York about revisiting the restructured electric utility industry. As in other restructured states, New York utilities have divested most of their generation and operate primarily as transmission and distribution companies which secure their power supply in the open market. ${ }^{302}$ A New York Assemblyman has claimed that "deregulation is a flop," and he introduced legislation that required utilities to sign long-term contracts and required the state to generate more power. ${ }^{303}$ In support of his proposal, the Assemblyman cited a study ${ }^{304}$ showing that prices in New York had increased by about 38 percent from 2000 to $2007,{ }^{305}$ as compared to the 27 percent price increases during the same period in the "regulated" states. ${ }^{306}$ According to the Assemblyman, the problem with the restructured system is that "prices bear no relation to cost" inasmuch as generators receive a clearing price for their power based on the last, most expensive MWh produced, regardless of actual costs of production. ${ }^{307}$ Under a return to traditional regulation, utilities could own generating units and enter into long-term power purchase agreements, and retail electric rates would be set based on the actual costs incurred by the utility rather than the market-based price from the wholesale market.

to Approve PPL Plan to Make Extended Bid for Post Rate-Cap Power, GloBal POWER RePORT, May 17, 2007, at 19 [hereinafter PPL Plan].

300. Bonner, supra note 300 .

301. Id.

302. In its May 1996 order in the Competitive Opportunities Case, the New York Public Service Commission (NYPSC) required electric utilities to submit restructuring plans by October 1996. Between July 1996 and February 1998, the NYPSC approved restructuring plans for Orange \& Rockland Utilities, Consolidated Edison, Rochester Gas \& Electric, New York State Electric \& Gas, Central Hudson Gas \& Electric, and Niagara Mohawk, respectively. NEW YORK STATE ASSEMBLY, SHEDDING LIGHT ON THE GOVERNOR'S FAILED ELECTRIC UTILITY RESTRUCTURING: A BRIEFING PAPER ON MOVING TO COMPETITION IN THE ELECTRIC INDUSTRY (Feb. 1999), available at http://www.assembly.state.ny.us/Reports/Energy/199902/.

303. New York Assemblyman Calls for Return to Long-Term PPAs to Lower State's Rates, GLOBAL POWER REPORT, Sept. 20, 2007, at 30.

304. Id. The Assemblyman commissioned a study by Marilyn Showalter, executive director of Power in the Public Interest, which compared electric rates in "deregulated" versus regulated states. Id.

305. Id. (from 10.4 cents $/ \mathrm{kWh}$ to 14.4 cents $/ \mathrm{kWh}$ ). Id.

306. Id. (from 6.0 cents $/ \mathrm{kWh}$ to 7.6 cents $/ \mathrm{kWh}$ ) Id.

307. PPL Plan, supra note 299 , at 30. 


\section{Michigan}

Michigan's restructuring law, enacted in June 2000, provided for an immediate five percent rate reduction for residential customers of The Detroit Edison Company (Detroit Edison) and for Consumers Energy Company (Consumers Energy), followed by capped rates through December 31, 2005. ${ }^{308}$ Following the initial years of Michigan's electric choice programs, in which participation levels were steady, competition in Michigan's electric market declined considerably in both 2005 and 2006. During 2005, the number of customers participating and overall megawatt load served in Michigan's electric choice market fell by approximately 20 percent and 40 percent, respectively. ${ }^{309}$ During 2006 , the total number of choice customers and associated megawatts of load receiving service under the choice programs were approximately 51 percent and 43 percent less, respectively, than in $2005 .{ }^{310}$ The decline in choice enrollments and electric load for the second year in a row was attributed largely to significantly higher wholesale electricity prices compared to relatively lower utility power supply rates. ${ }^{311}$

In the spring of 2007, the utility industry commenced an effort to roll back the Michigan Restructuring Act. In testimony before the Michigan House of Representatives' Energy and Technology Committee, Detroit Edison's Chief Executive Officer urged Michigan lawmakers to scrap the electric choice law, claiming it "severely restricts" efforts by utilities to invest in new base load generation. ${ }^{312} \mathrm{He}$ described the law as leaving the state's electric industry "partly regulated and partly unregulated," which "creates uncertainties for all electricity suppliers.",313 Subsequent testimony by several independent power producers, however, revealed willingness to consider building new power plants in Michigan if the Restructuring Act were retained. ${ }^{314}$ The House Energy and Tech-

308. The Customer Choice and Electric Reliability Act, 2000 Mich. Pub. Acts 141 (Michigan Restructuring Act).

309. Status of Electric Competition in Michigan, Report for Calendar Year 2005, at 1 (Michigan PSC Feb. 1, 2006).

310. Status of Electric Competition in Michigan, Report for Calendar Year 2006, at 3 (Michigan PSC Feb. 1, 2007).

311. Id. Upon expiration of the rate cap, on January 1, 2006, Detroit Edison implemented a 7\% increase for residential customers. Case No. U-13808, Order Issued November 23, 2004. Consumers Energy also increased its rates by $\$ 86$ million on January 1, 2006, upon expiration of the rate caps. Case No. U-14347, Order Issued December 22, 2005.

312. DTE Energy CEO Calls for End to Michigan's Electric Choice, Citing Investment Concerns, GlOBAL POWER REPORT, Apr. 19, 2007, at 24.

313. Id.

314. IPPs Back Electric Choice in Michigan; Express Interest in Building New Plants, GLOBAL POWER REPORT, May 17, 2007, at 26. 
nology Committee took additional evidence in December 2007 regarding the Michigan Restructuring Act but took no vote. ${ }^{315}$ According to a February 1, 2008 report from the Michigan PSC, the legislature was "working on a multi-bill package of reforms and updates to existing acts governing the electric industry" that, if enacted, would "affect the status of electric competition in Michigan for many years to come."316

\section{Maine}

During the 2007 legislative session, the Maine legislature adopted a resolution requiring the Maine Public Utilities Commission (Maine PUC) to undertake a review of the issues involved with the "re-entry" of the Maine electric utilities into the electric supply business. ${ }^{317}$ Following the adoption of the Restructuring Act in 1997, ${ }^{318}$ Maine electric utilities were required to divest most of their generation assets, becoming "wires" companies. The 2007 Resolution was adopted as a compromise following action by a legislative committee to block attempts by Maine utilities to get back into the generation business. ${ }^{319}$ The state's utilities had been pushing for the ability to get back into the generation business, arguing that restructuring had failed to deliver promised rate relief for small customers. ${ }^{320}$ According to one observer, however, "Maine is considered one of the more successful restructured states because a large portion of its business customers have switched to competitive suppliers, electric rates are relatively low, and capacity remains plentiful., ${ }^{, 321}$

315. Global Power Report, Utilities Seek Roll-back of Customer Choice in Michigan to Support Plans to Build New Plants, Dec. 20, 2007, at 26.

316. Status of Electric Competition in Michigan, Report for Calendar Year 2007, at 21 (Michigan PSC Feb. 1, 2008).

317. 2007 Me. Laws Ch. 54 (Resolves) (2007), available at http://janus.state.me.us/legis/ros/lom/LOM123rd/RESOLVE54.asp.

318. 1997 Me. Laws Ch. 316 (1997), available at http://janus.state.me.us/legis/ros/lom/LOM118th/LOM271to350-45.htm\#P1213_212015.

319. Maine Committee Blocks Bills to Allow Utilities to Return to Generation in Deregulated State, GLOBAL POWER REPORT, May 17, 2007, at 26.

320. Id. Under "re-entry," utilities would re-enter the generation business by either building or owning power plants, or by signing long-term power supply deals with generators.

321. Id. In December 2004, the power procurement auction resulted in a nearly 30 percent increase in the electric standard offer price for residential and small commercial customers due to the significantly higher costs associated with producing electricity in the New England region. 2004 Annual Report on Electric Restructuring, at 4 (Me. PUC Dec. 31, 2004), available at www.maine.gov/mpuc/staying_informed/legislative/2005legislation/ERR-Report-final.pdf. In October 2000, the Maine PUC had approved a 33 percent increase for customers served under BangorHydro Electric Company's standard offer, which resulted from rising oil and natural gas costs. The 2002 Annual Report noted that during 2001, the wholesale market exhibited volatile and sometimes high generation prices, which resulted in high retail prices for consumers and difficulties in procuring and administering standard offer service." 2002 Annual Report on 
In accordance with the 2007 Resolution, the Maine PUC commenced a proceeding to gather information, viewpoints, and recommendations from interested persons on the issues raised in the 2007 Resolution. In its January 15, 2008 Report to the Utilities \& Energy Committee, the Maine PUC recommended against any immediate legislative changes that would allow the state's utilities to re-enter the business of owning generating assets. ${ }^{322}$ In 2006 , the Maine legislature had previously authorized the Maine PUC to direct two of Maine's utilities, Central Maine Power and Bangor-Hydro Electric Company, to enter into long-term contracts for capacity and associated energy, and the report concluded that there should be "a sufficient opportunity to test the potential to achieve" benefits for customers through long-term contracting before allowing utilities to own generation. ${ }^{323}$ It should be noted that no commenter in the proceeding suggested a complete retreat from electric restructuring and a return to vertically integrated electric utility monopolies. ${ }^{324}$ The "re-entry" proposal under consideration would have allowed investor-owned utilities to own or obtain an interest in generation assets on a "regulated" basis so that their customers, who would pay for these assets on a cost-of-service basis, would have some "hedge" against open market prices. ${ }^{325}$

\section{Montana}

In May 2007, the Montana legislature enacted House Bill 25, which reversed many of the provisions of the Electric Utility Industry Restructuring and Consumer Choice Act (Montana Restructuring Act) passed in April 1997. ${ }^{326}$ The Montana Restructuring Act provided for a two-year rate freeze beginning in July of 1998 and called for retail access for large industrial customers by July 1998 and for all consumers by July 2002 (subsequently delayed until July 2004 by the Montana Public Service Commission). Under House Bill 25, which became effective on October 1, 2007, the Restructuring Act's customer-choice provision, which

\footnotetext{
Electric Restructuring, at 5 (Me. PUC Dec. 31, 2002), available at www.maine.gov/mpuc/staying_informed/legislative/2002legislation/ERR-RPT.pdf.

322. Report on Transmission \& Distribution Utilities Participation in the Energy Supply Business, at 17 (Me. PUC Jan. 15, 2008).

323. Id. at 18 .

324. Id. at 6 .

325. Id.

326. 2007 Mont. Laws Ch. 491.
} 
allowed customers to shop rates and switch back and forth between utilities, was eliminated. ${ }^{327}$

\section{CONCLUSION}

Under each of the state restructuring experiences examined in this Article-Maryland, Delaware, Virginia, Illinois, and Ohio-the "transition" to market-based rates involved (or will involve, in the case of Ohio) a significant increase in retail electric rates. Over the term of the rate freezes or rate caps adopted in each state, the power costs borne by the utility and the revenues recovered by the utility ceased to track. This outcome was the result of a combination of circumstances, including the failure of anticipated competition to materialize and to provide hoped-for benefits and the substantial increases in underlying costs of fuels used to produce the wholesale power supply. Regardless of the cause, however, upon expiration of the rate cap and upon undertaking the required re-examination of the utility's financial circumstances, it was clear that the imbalance needed to be corrected if the utility were to maintain its financial integrity and ability to attract and retain capital.

The constitutional arguments available to the utilities were twofold: (1) the Takings Clause of the Fifth Amendment (as applicable to state action through the Fourteenth Amendment); and (2) the Due Process Clause of the Fourteenth Amendment. Although the Takings Clause and Due Process Clause claims are factually interrelated and are often brought in tandem in challenges to governmental rate or price-control regulations, each is a distinct basis for challenge. The Takings Clause claim has strong support in U.S. Supreme Court cases involving utility ratemaking, and the principle that a utility is entitled under the Constitution to a fair rate of return as a matter of Takings Clause jurisprudence is well-established, most recently in Duquesne. As a practical matter, however, the argument of unconstitutionality "as applied" under the Takings Clause is fraught with peril for the utility. This is because of the evidentiary challenges of making the financial showing and because of the deference that would be accorded regulators in determining the "fair" rate of return required to avoid the constitutionally prohibited confiscatory rate.

As discussed in this Article, under certain circumstances a Due Process Clause challenge is also available where the effect of the state action is to deny a mechanism under which the utility would have an opportunity to make its Takings Clause claim. The burden of prevailing on

327. Legislation in Montana that would Repeal State's Restructuring Law Passes in Senate, GLOBAL POWER REPORT, Apr. 12, 2007, at 22. 
a Due Process Clause constitutional premise provides a far easier path for a utility seeking to preserve (or restore) its financial health in the context of rehabilitation of a state restructuring regime. Where a state perpetuates a utility's under-recovery of costs such as through extension of a rate plan-as was enacted in Illinois, was considered in Maryland and Delaware, and apparently is under consideration in Ohio - the practical effect is to deny the utility the mechanism to make its Takings Clause case. Under the precedent established in the series of cases discussed in this Article, the availability of this Due Process Clause challenge will likely be of increasing relevance as states continue to struggle with the results of their restructuring regimes. 